\title{
'Hellenistic' House in Nea Paphos, Cyprus A First Summary of Its Architecture
}

\author{
AlEKSANDRA BrzozowsKa-JaWORniCKA
}

\begin{abstract}
This paper presents preliminary observations and analyses of the architecture of the 'Hellenistic' House, an ancient residency from Roman times built in Nea Paphos on Cyprus. The House was erected as an extensive edifice around several courtyards of a very interesting architectural frame and rich decoration. Unfortunately, the residence was destroyed by an earthquake and afterwards rebuilt with new edifices, primarily the Villa of Theseus, and as such its remains are in a very poor state. However, the preserved fragments of walls, floors, technical infrastructure as well as pieces of architectural decoration permit the conducting of architectural studies of the residence's layout, structure and functional arrangement.
\end{abstract}

Keywords: ‘Hellenistic’ House, Nea Paphos, Roman period Cyprus, ancient residence

Aleksandra Brzozowska-Jawornicka, Department of History of Architecture, Art and Technology, Faculty of Architecture, Wrocław University of Science and Technology, Wroclaw; aleksandra.brzozowska-jawornicka@pwr.edu.pl; (D) 0000-0003-0695-3016

The 'Hellenistic' House was one of many residences built in Nea Paphos, an ancient city located on a peninsula on the south-western coast of Cyprus (Fig. 1). The city was founded in the fourth century $\mathrm{BC}$ in accordance with the most current Hellenistic urban guidelines of the times - an orthogonal grid plan with crossing streets that created repetitive insulae. The House was uncovered by the Polish Archaeological Mission of the Polish Centre of Mediterranean Archaeology, University of Warsaw, during many seasons of archaeological research which started in $1986 .{ }^{1}$ The last extensive excavations of the area in question were conducted in $2016 .^{2}$

\footnotetext{
${ }^{1}$ Until 2007, Wiktor A. Daszewski was the director of the Polish Mission in Maloutena. From 2008 to 2019 it was supervised by Henryk Meyza. Presently Ewdoksia Papuci-Władyka is in charge of the Polish team in Nea Paphos. Selected literature: Daszewski 1985; 1990: 35; 1991: 82-84; 1992a: 63-66; 1992b; 1993: 88-93; 1994: 101-109; 1995: 67-71; 1996: 91-97; 1997: 113-120; 1998: 119-125; 1999: 163-167; Daszewski et al. 2004: 289-290; 2007: 403-407; 2008: 511-517; 2010: 509-512; Karageorghis 1987: 685-687; 1988: 836-838; 1989: 833-834.

${ }^{2}$ Meyza et al. 2017.
} 


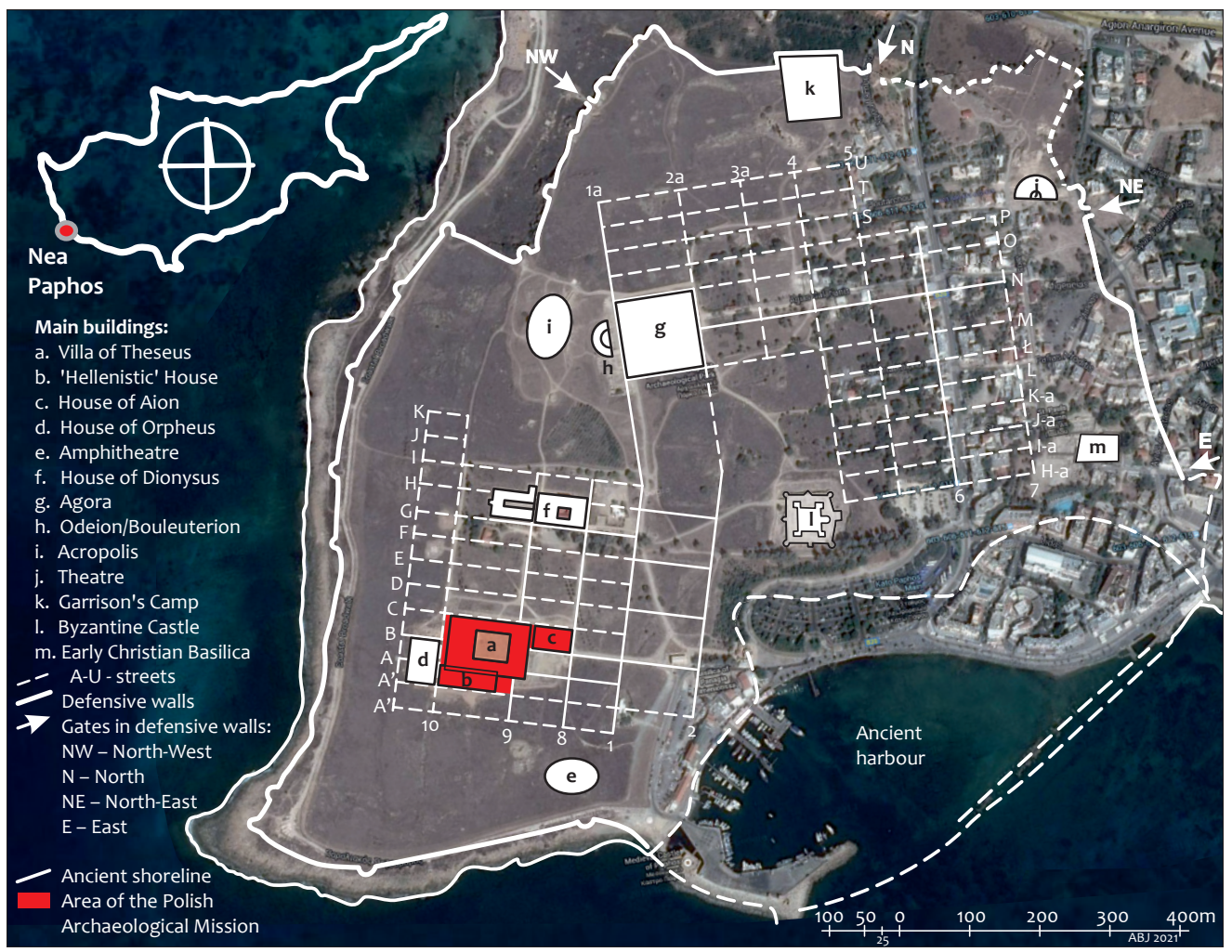

1. Map of Nea Paphos (Based on: Medeksza 1998: 37, Fig. 1; Młynarczyk 1990: 162, Fig. 16; retrieved from Google Earth, status as of October 5, 2014).

The 'Hellenistic' House was built to the south of the Paphian agora, where many rich residences were erected, ${ }^{3}$ among others the House of Dionysus, the House of Orpheus, the 'Hellenistic' House, the Villa of Theseus and the House of Aion, the last three uncovered by the Polish Mission (Fig. 2).

This paper focuses on analysis of the last, extensively uncovered and investigated phase of the architectural remains of the 'Hellenistic' House dated to the late first-early second century $\mathrm{AD}^{4}{ }^{4}$ At that time Cyprus was under Roman rule, which makes the name given to the uncovered residence inconsistent. The House was named at an early stage of the excavations, when a floor made of irregular fragments of pebbles in the residence main hall was discovered. As this mosaic was similar to the ones from the Hellenistic period and other conclusive dating indications were missing, the name 'Hellenistic' House seemed appropriate. However, later discoveries proved that the House was erected during the Roman period, but its name had already been established and was present in the literature.

\footnotetext{
3 Młynarczyk 1990: 184-193.

4 Meyza et al. 2017.
} 


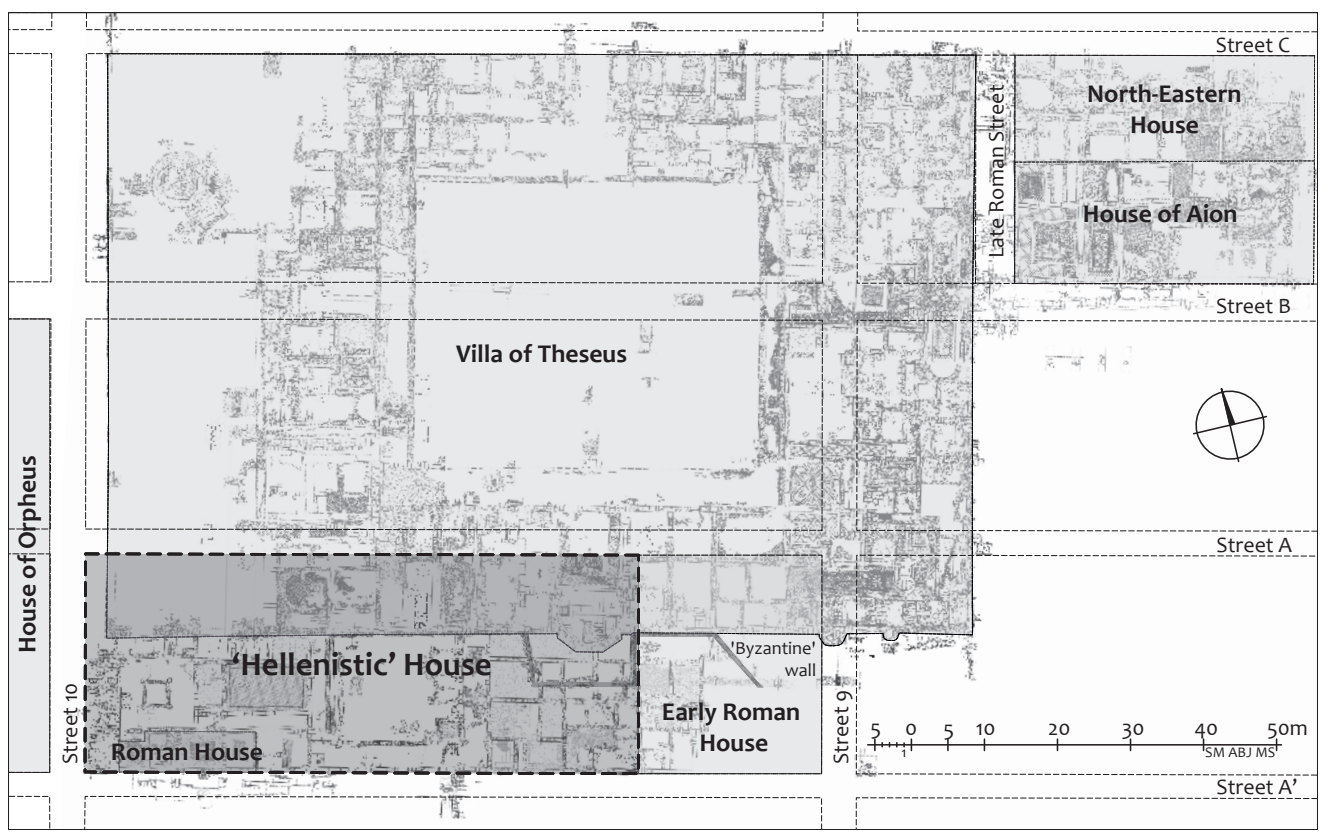

2. Plan of the Paphian residences (Drawing: S. Medeksza, A. Brzozowska-Jawornicka, M. Słowińska).

The 'Hellenistic' House was occupied for only a handful of decades, and soon after its last extensive rebuilding was destroyed by an earthquake, never to be rebuilt again. ${ }^{5}$

The main subject of the paper is to present the uncovered architectural structures, rooms, compartments and layout of the residence. Detailed issues of building technology, water installations, wall-paintings, mosaics, as well as the interpretation of the functions of particular rooms and their equipment are not the topic of this article, although some references in this respect will be presented. The dating of the analysed last phase of the 'Hellenistic' House is based mainly on studies of pottery and other small objects, as analysis of the architectural remains does not provide a precise chronological framework (see also below). ${ }^{6}$

\section{THE INSULA OF THE ‘HELLENISTIC’ HOUSE}

The 'Hellenistic' House was located in a rather densely build up area composed of wealthy houses and relatively narrow streets, approximately $5 \mathrm{~m}$ wide. ${ }^{7}$ It was built within a longitudinal insula with its longer axis running east-west and the shorter one north-south. It occupied about $75 \%$ of the insula's area on its western side (Fig. 2).

\footnotetext{
${ }^{5}$ Meyza et al. 2017.

${ }^{6}$ The elaboration of many of the initially outlined threads in this article will be discussed in detail in the planned the monograph of the 'Hellenistic' House.

7 Daszewski 1994: 109.
} 
The edifice was delimited by three streets: the 10 from the west, the $\mathrm{A}$ from the north and the A' from the south. ${ }^{8}$ Another, at least partly contemporary(?) building, the so-called Early Roman House, was erected in the eastern quarter of the insula. The border between the two houses runs between rooms 4, 7 and 6 of the Early Roman House and rooms 18N, 18S, 19, 19S, 24 and 25 of the 'Hellenistic' House (Fig. 3). The orientation of both houses is the same, i.e. their walls and general layout are similar, which may indicate that originally the insula had been built with one larger homogeneous structure that was subsequently subdivided into two independent units. ${ }^{9}$

As mentioned above, the 'Hellenistic' House was fatally ruined by an earthquake. ${ }^{10}$ Several new buildings were erected on its ruins (Figs 2-3). Shortly afterwards, in the second half of the second century AD the whole northern part of the House, was built up with the Villa of Theseus. ${ }^{11}$ The destruction was almost complete, as foundations of the Villa were laid below those of the 'Hellenistic' House and did not follow the layout of the older edifice. The only remnants that survived were small fragments of the foundations preserved deep beneath the floors of the Villa and uncovered in several trenches. ${ }^{12}$

Similarly to the Villa of Theseus built over the northern part of the 'Hellenistic' House, the Roman House was erected above its south-western part, probably at a comparable time, i.e. in the second half of the second century AD. The fundamental difference between the Villa of Theseus and the Roman House in the context of the 'Hellenistic' House, besides the scale of the houses, lies in the use of the structures of the latter: the Villa's layout is completely new, in contrast to the Roman House where at least parts of the preserved older walls were incorporated into the new construction. ${ }^{13}$

Much later, another structure emerged on the ruins of the 'Hellenistic' House: the so-called Byzantine wall was built over the north-eastern rooms of the edifice. ${ }^{14}$

Many of the ruined walls of the 'Hellenistic' House were removed in antiquity providing a source of building material for the Maloutena region. ${ }^{15}$ The undeveloped space of the former 'Hellenistic' House, especially the area of its Main Courtyard was transformed

${ }^{8}$ Daszewski 1994: 108-109; 1997: 118-120; Daszewski et al. 2010: 512; Karageorghis 1989: 834; Meyza et al. 2011: 289, 293; Młynarczyk 1990: 173-174.

${ }^{9}$ Daszewski 1996: 97; 1998: 125; Daszewski et al. 2008: 515-517; Daszewski et al. 2010: 509. There are also other proofs that the insula in question was most probably densely built-up before the erection of the 'Hellenistic' House. Excavations conducted within its Main Courtyard uncovered remains of structures older than the last phase of the 'Hellenistic' House, among others remnants of two rectangular basins and a much smaller round pool (see e.g.: Daszewski 1994: 102-103; Daszewski et al. 2004: 290; 2008: 515-517; Meyza et al. 2011: 291; 2012: 418-420; 2017: 399-417; Romaniuk 2017). The exact relations between the last phase of the 'Hellenistic' House and the earlier structures built in the same area require further studies.

10 Traces of earthquake are visible in almost every room of the 'Hellenistic' House, hence all the archaeological reports refer to seismic events. Selected literature: Daszewski 1991: 82; 1994: 101-102; Meyza 2015: 447-448.

11 Daszewski 1985; Medeksza 1992: 5, 17, 24, 30.

12 Daszewski 1995: 69-72, Fig. 2; Daszewski et al. 2007: 403; 2008: 511.

13 Daszewski 1993: 93; 1994: 105, 107-109; 1995: 72; 1996: 92; Meyza et al. 2017: 417-419.

14 Daszewski et al. 2007: 403; 2008: 511.

15 Daszewski 1993: 93. 


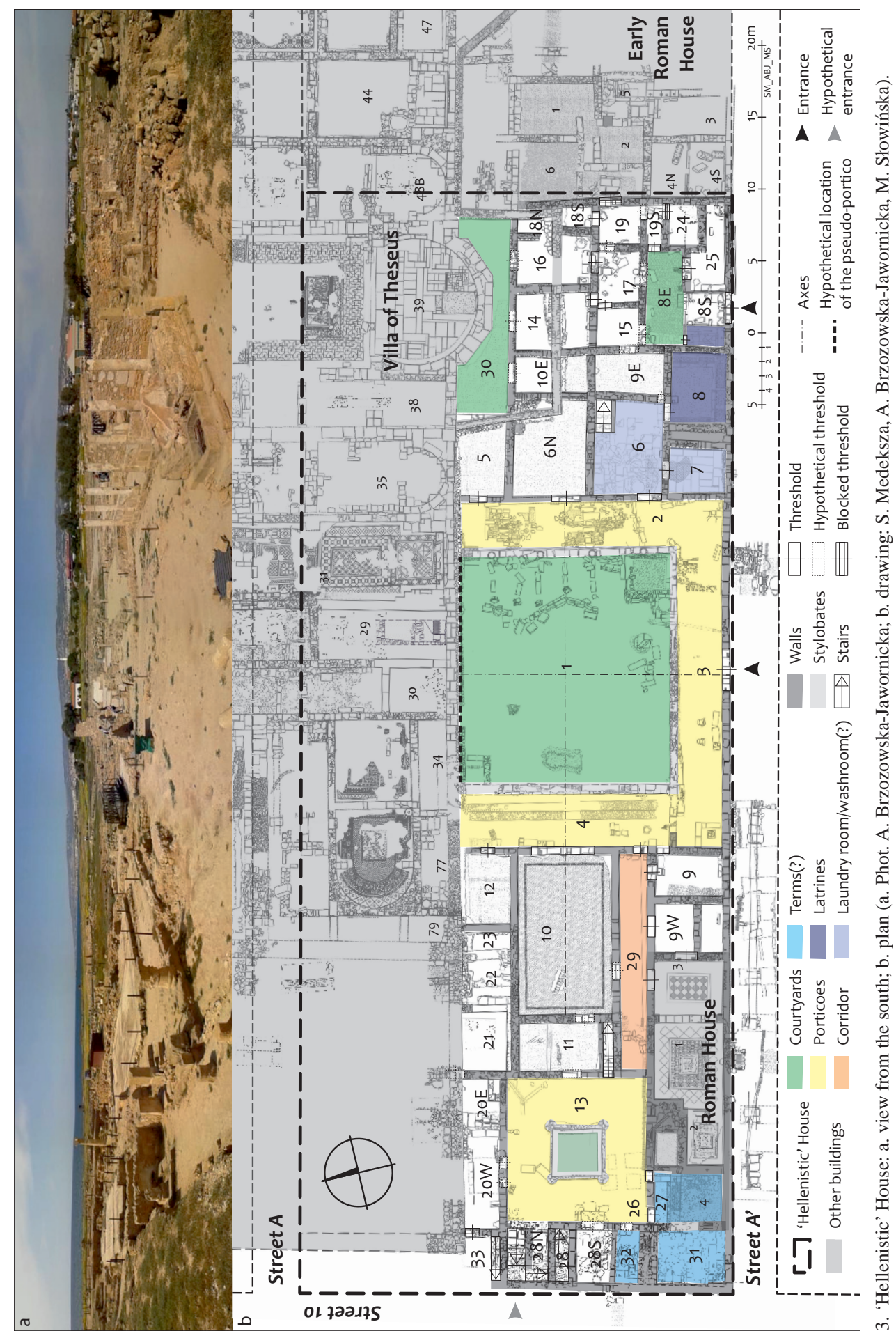


into rubble, where construction debris from the ruins of the destroyed buildings, particularly from the area of the future Villa of Theseus, was stored. These remains contained many plain blocks as well as fragments of architectural decoration and served as a warehouse for easy-to-get building material for the newly built edifices in that part of Nea Paphos. The architectural decorative elements were reused rather rarely according to their nature, i.e. they were re-cut to a new shape and/or embedded into the walls of the subsequent buildings.

However, the uncovered remains of the walls, floors and fragments of the technical infrastructure of the 'Hellenistic' House, as well as pieces of the architectural decoration found in the areas of its two courtyards and identified as belonging to the original embellishment of the House, allowed us to recreate to a certain degree the genuine architectural form of some parts of the residence.

\section{SPATIAL ARRANGEMENT OF THE ‘HELLENISTIC’ HOUSE}

The 'Hellenistic' House covered an area of around 2,280 $\mathrm{m}^{2}$, with $76 \mathrm{~m}$ on the east-west axis and 30m on north-south one. The House was built up around several courtyards (Fig. 3), each one placed in another part of the edifice. The Main Courtyard (HH1) lies in the central part of the residence. The Western Courtyard (HH13) is much smaller and was erected as an atrium. In the eastern part of the House at least two courtyards were designed: room 30 in the north and room 8E in the south.

The courtyard was a crucial functional and compositional element of a typical residence layout in Graeco-Roman society for several reasons. Firstly, it was surrounded by rooms and therefore provided access to different parts of the house. Secondly, it supplied the interior of the residence with air, light and water collected in basins or cisterns, as well as ensuring privacy and tranquillity for the residents. ${ }^{16}$ The 'Hellenistic' House is no exception to this rule.

\section{Peristyle Of The ‘Hellenistic’ House (HH1-4)}

The Main Courtyard (HH1) of the 'Hellenistic' House lies in the central part of the residence (Figs 3-5). During many years of excavations its area was completely uncovered to show an open courtyard surrounded by three porticoes from the west, south and east. Behind the western and eastern porticoes there were other rooms of the residence, while the southern portico bordered directly with street A'. The destruction of the northern part of the 'Hellenistic' House ${ }^{17}$ hinders reconstruction of the courtyard's form, but the unearthed southern part with the adjacent rooms, the preserved pieces of architectural decoration and

\footnotetext{
16 Ellis 2000: 136-137; Jashemski et al. 2018: 341-481; Wallace-Hadrill 1997: 231.

17 Meyza et al. 2017.
} 


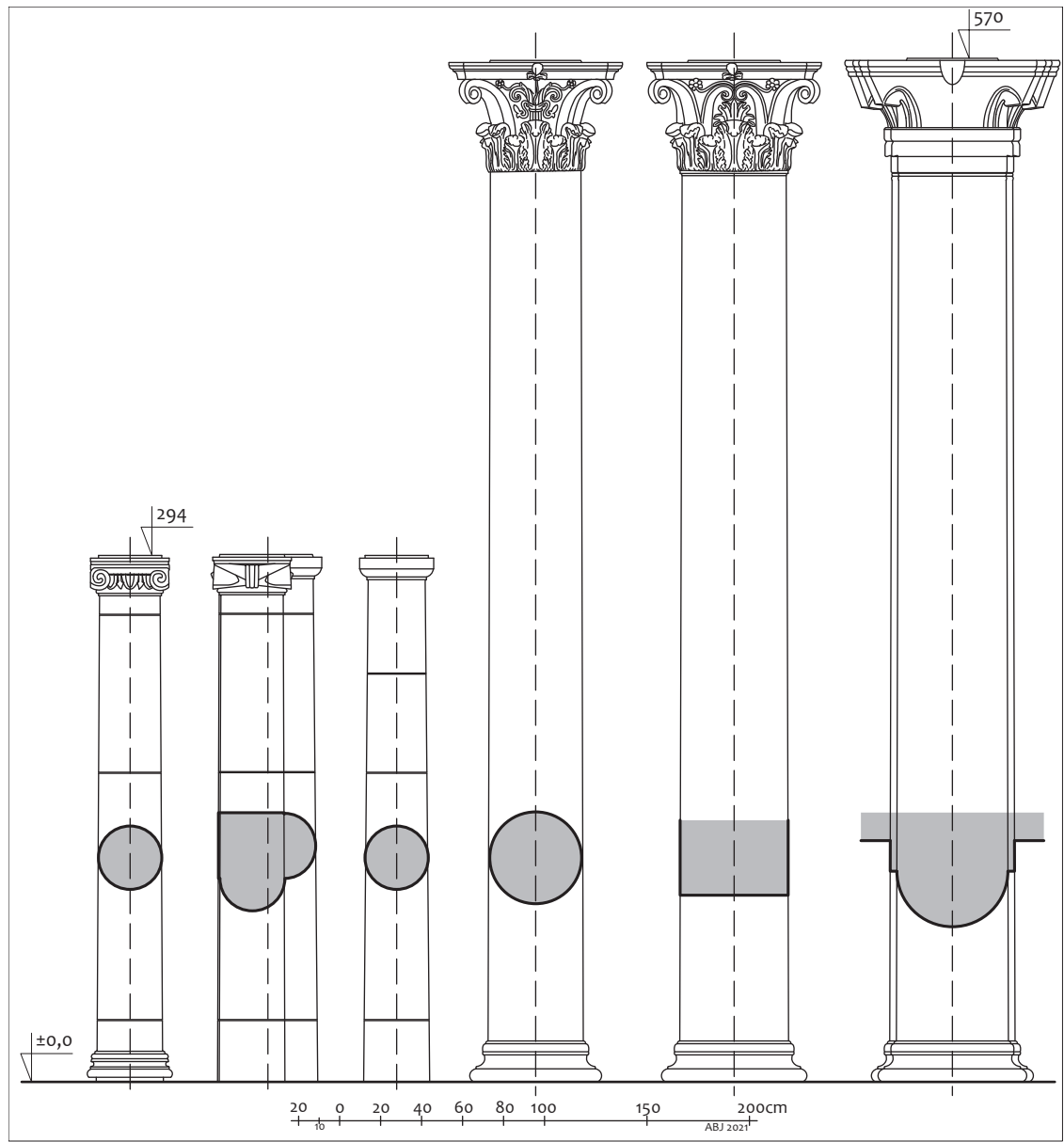

4. Peristyle of the 'Hellenistic’ House: supports of the porticoes (Drawing: A. Brzozowska-Jawornicka).

fragments of foundations uncovered in the Villa of Theseus ${ }^{18}$ allow us to propose some hypotheses concerning the original form of this courtyard.

The preserved part, including the porticoes, is $432 \mathrm{~m}^{2}$, i.e. $24 \mathrm{~m}$ (W-E) by $18 \mathrm{~m}(\mathrm{~N}-\mathrm{S})$. The courtyard's open area measures $15.6 \mathrm{~m}$ (W-E) by $14.35 \mathrm{~m}(\mathrm{~N}-\mathrm{S})$, i.e. $224 \mathrm{~m}^{2}$. The widths of the western, southern and eastern porticoes are: almost $4 \mathrm{~m}, 3.2 \mathrm{~m}$ and $3.1 \mathrm{~m}$ respectively. ${ }^{19}$

The beaten floor made of green clay (khonnos) was found inside the southern portico. ${ }^{20}$ The other porticoes were presumably paved with floors of the same type, while the open area of the courtyard was filled with a thick layer of fertile soil, which may indicate the exis-

18 Daszewski 1995: 69-72, Fig. 2.

19 Daszewski 1990: 35; 1992a: 65; Karageorghis 1989: 834.

20 Meyza 2015: 446-447. 


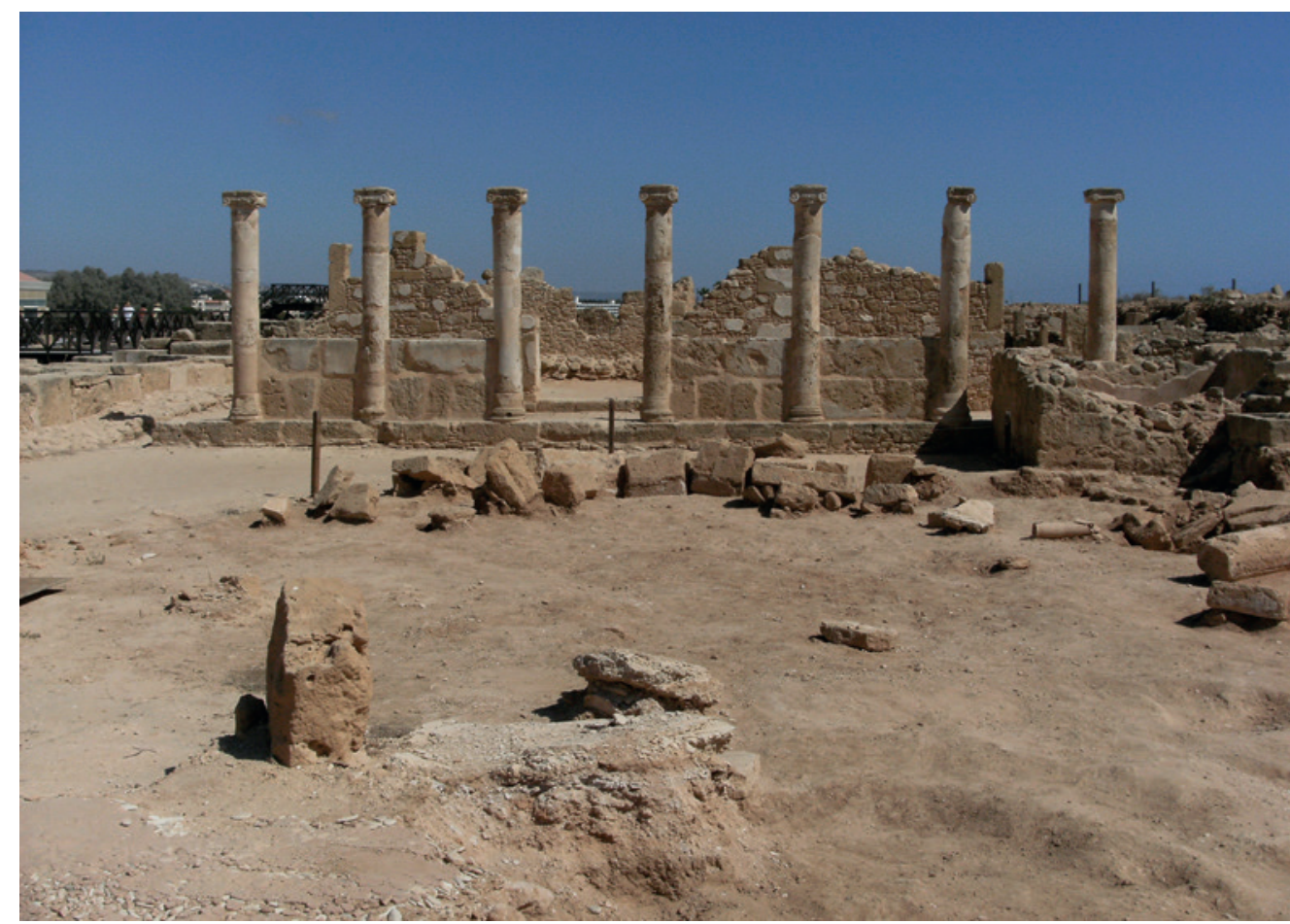

5. Peristyle of the 'Hellenistic' House: reconstructed southern part of the eastern Ionic portico (Phot. A. BrzozowskaJawornicka).

tence of a garden there, ${ }^{21}$ an arrangement known from courtyards of other Graeco-Roman residences, e.g. in Greece. ${ }^{22}$

Many pieces of architectural decoration were found in the courtyard which, as mentioned above, had been transformed into rubble after the destruction of the 'Hellenistic' House. Some of these fragments were identified as parts of the original structures of the courtyard. ${ }^{23}$

The eastern portico (HH2) turned out to be the best preserved of all the courtyards: it collapsed towards the west into the courtyard and its fragments were left there to be excavated. Seven columns creating the southern part of the colonnade were found. The northern side was removed during the erection of the Villa of Theseus. The portico was composed of slightly simplified Ionic columns, with plain shafts, measuring $2.94 \mathrm{~m}$ in height with a diameter of $38 \mathrm{~cm}$ and spaced approximately every $1.8 \mathrm{~m}$. A stone balustrade was mounted between the columns, which were crowned with an entablature probably made of unpreserved wooden architraves and plain slabs imitating simplified cornice. ${ }^{24}$

21 Daszewski 1994: 103-104; Meyza et al. 2017.

22 Bonini 2006: 62-65.

23 Brzozowska-Jawornicka forthcoming.

${ }^{24}$ Brzozowska-Jawornicka forthcoming; Karageorghis 1988: 837; 1989: 834; Meyza 2015: 444. 
The southern portico (HH3) was almost completely destroyed and its fragments were subsequently removed including slabs from the stylobate. However, a few pieces of columns were excavated around this area. Five capitals allowed us to establish that the colonnade had been erected in a slightly simplified Doric order ${ }^{25}$ and was equal to the Ionic portico in terms of the columns' height and, consequently, most likely its intercolumniation and entablature. ${ }^{26}$

The two porticoes were connected by a shared corner support in the form of a composite heart-shaped pillar crowned with two halves of capitals - Doric and Ionic. ${ }^{27}$

Another set of decorative architectural fragments found within the Main Courtyard constitutes the basis for the reconstruction of the western portico (HH4): an anta base preserved in situ on the southern corner of the portico stylobate; a column's base with mouldings similar to those of the anta base, and four capitals of the size matching the bases, two belonging originally to antae and a pair of crowning columns. ${ }^{28}$ Analysis of these finds proved that: firstly, it was erected in the Corinthian order in a special variation known from the territory of the Ptolemaic Kingdom and called the Alexandrian style; ${ }^{29}$ secondly, the columns measured around $5.7 \mathrm{~m}$ in height with a diameter of $53 \mathrm{~cm}$, so they were much higher than the eastern and southern ones. ${ }^{30}$ The intercolumniation and entablature of this portico are unknown.

It is worth emphasising that the western portico was highlighted by various design features: it was wider and higher than the southern and eastern porticoes and it was erected in the Corinthian order, the most decorative of all styles. Such a rich architectural frame of this particular portico, far more imposing than the others, was due to the fact that the most important room of the whole 'Hellenistic' House - the residence reception hall (HH10; see below) - was placed behind it.

Regarding the northern missing side of its Main Courtyard, a trench that was opened in room 29 in the Villa of Theseus, north of the uncovered part of the courtyard, revealed the presence of three walls of west-east axes that could be identified as the foundation of walls or structures belonging to the 'Hellenistic' House. It has been suggested that the northernmost of these walls could have belonged to the northern portico of the Main Courtyard. ${ }^{31}$

Subsequent fragments of the architectural decoration excavated in the area of the Main Courtyard constituted an additional source of information concerning its northern missing part. A set of about forty small pieces of literally crushed capitals was found within the rubble. They were identified as parts of the so-called blocked-out capitals, derivative

${ }^{25}$ Daszewski 1992a: 65; Meyza 2015: 445-446.

${ }^{26}$ Brzozowska-Jawornicka forthcoming.

27 Brzozowska-Jawornicka forthcoming; Daszewski 1990: 35; Karageorghis 1989: 834.

${ }^{28}$ Brzozowska-Jawornicka forthcoming; Daszewski 1990: 35; 1992b: 253-254; Papageorghiou 1990: 997, Fig. 97; Meyza et al. 2014: 399-400, Fig. 12.

29 Brzozowska-Jawornicka forthcoming; Papageorghiou 1990: 977.

30 Daszewski 1991: 83; Meyza et al. 2014: 400; 2017: 399-401.

31 Daszewski 1995: 69-72, Fig. 2. 
of the Corinthian capitals resembling Nabatean capitals type $1 .^{32}$ The reconstructed form of the missing capitals permits establishing two crucial features of the northern side of the Main Courtyard. Firstly, their size was similar to the Corinthian capitals from the western portico, which proves that both were equal in height. Secondly, the particular attributes of these fragments, especially the occurrence of two variants of the capitals' corners and their twist, points to a very unusual form of engaged support: a half-column on a pilaster. Such a kind of support makes the northern side of the Main Courtyard a pseudo-portico instead of a classical one. ${ }^{33}$

Generally, the main courtyard of affluent ancient Roman residences was usually designed as a peristyle, ${ }^{34}$ i.e. an extensive square or rectangular open space surrounded by roofed colonnades. ${ }^{35}$ The porticoes protected the residents against rain and provided shadow in the hot climate. The peristyle usually had at least one axis of symmetry emphasising the residence's important areas, e.g. the main room or the entrance. The main courtyard was also an area where the owner of the house could demonstrate his position in society by e.g. rich architectural embellishment. So, were these classical features of a standard peristyle present in the Main Courtyard of the 'Hellenistic' House?

The courtyard was surrounded by porticoes to the west, south and east, and a pseudoportico to the north. Such an arrangement makes the courtyard a peristyle, although courtyards with pseudo-porticoes are sometimes called pseudo-peristyles. They were usually designed in smaller houses with no space for a more spacious courtyard with porticoes, e.g. in ancient Alexandria with a very dense urban layout. ${ }^{36}$

Establishing the form of the northern side of the courtyard, i.e. a continuous wall with engaged supports, does not define the position of this structure within the residence, and as a consequence the layout of the courtyard. If we assume that the northern-most of three above-mentioned walls uncovered below room 29 of the Villa of Theseus was in fact the foundations of the northern pseudo-portico, the open area of the courtyard would have been rectangular and measured around $20.5 \mathrm{~m}$ from north to south and $15.6 \mathrm{~m}$ from east to west. Therefore, its east-west axis of symmetry would have been shifted by about $2.5 \mathrm{~m}$ to the north in relation to the symmetry axis of the reception hall (HH10) located behind the western portico. As classical architects preferred symmetry, such an arrangement seems rather unlikely.

However, if we assume that the courtyard and the reception hall followed the same symmetry axis, we may theoretically calculate the position of the potential foundations of the northern missing pseudo-portico and the width of the open area of the courtyard: it would have also been rectangular, but measured around $14.5 \mathrm{~m}$ from north to south.

${ }^{32}$ Meyza 2015: 450-451; Brzozowska-Jawornicka forthcoming.

${ }_{33}$ Brzozowska-Jawornicka forthcoming.

${ }^{34}$ Medeksza 1992: 42-43.

${ }^{35}$ Hales 2003: 208-209.

${ }^{36}$ Selected literature: Majcherek 1995; 1997: 22-30, Figs 1-2; 2000: 32-34, Fig. 5; McKenzie 2007: 150, 180-183, 210, Figs 309, 310a. 
The location of the foundations of the pseudo-portico would have been directly below the southern outer wall of the Villa of Theseus, which could potentially explain the lack of preserved remains removed during the construction of the later residence. This second hypothesis and, consequently, the axis of the courtyard are confirmed at the other end of the peristyle: the east end of this axis was accentuated by a delicate widening of the eastern portico central span.

The course of the second symmetry axis of the peristyle, the north-south, does not raise any doubts, as the width of the courtyard is defined by the western and eastern porticoes' stylobates. However, the exact arrangements of the southern and northern sides of the courtyard remain unknown. We may only speculate whether that axis was also underlined by some architectural means, perhaps similar to those from the eastern portico, i.e. by emphasising the central spans of the Doric portico and the pseudo-portico.

An indirect confirmation of such an arrangement in the southern portico is the position of a wide threshold with holes for hinge door pins in the middle of the external wall of the Doric portico. As mentioned above, the outer wall of this portico also constituted the southern elevation of the 'Hellenistic' House on street A'. Perhaps the wider intercolumniation of the Doric portico central span had its reflection in the position of the main entrance to the residence. Placing the main gate to the House next to its Main Courtyard and reception hall seems to have been preferred in Graeco-Roman architecture ${ }^{37}$ and therefore highly possible. Unfortunately, the southern wall was almost completely removed in antiquity: only the lowest layers containing the threshold survived. Consequently, the form and scale of the residence main gate remain unknown.

Another intriguing feature of the residence peristyle is the height of its porticoes. The western and northern ones were significantly higher than the other two, as mentioned above. Such a configuration, with one portico of a peristyle higher than the others, was described by Vitruvius and named the 'Rhodian peristyle' ${ }^{38}$ It is known, among other things, from rich residences in Greece, e.g. the Casa Romana on $\operatorname{Kos}^{39}$ or Cyrenaica, e.g. the Domus of Great Peristyle, Domus of Giason Magnus, or Casa della Quattro Stagioni. ${ }^{40}$ The Main Courtyard of the 'Hellenistic' House seems to be an unusual example of this form.

The arrangement of the courtyard of the 'Hellenistic' House with its north-western half, composed of the blocked-out pseudo-portico and the Corinthian portico, almost twice as high as the south-eastern half, consisting of the Doric and Ionic porticoes, would look rather odd and certainly would not follow the ancient architectural canon. The introduction of the upper floor above the lower southern and eastern porticoes could be the solution: all the sides of the courtyard would have the same height, only the western and northern parts would be designed as a single high portico and pseudo-portico and on the

\footnotetext{
${ }^{37}$ E.g. Roman houses in Greece (Bonini 2006: 44).

38 Vitr., De arch. VI.7.3.

39 Bonini 2006: 298-300.

40 Pensabene, Gasparini 2020; Rekowska 2020; Stucchi 1975: 217-218, 297-299, 309, Figs 306-307, 320.
} 
eastern and southern sides there would be two storeys: porticoes with galleries leading to further rooms. ${ }^{41}$

The peristyle of the 'Hellenistic' House seems to have been a unique architectural masterpiece: a garden ${ }^{42}$ surrounded by four different structures: a high portico and pseudo-portico, and two lower porticoes topped with galleries, each of the four erected in a different architectural order. The courtyard constituted the official space of the residence and was used as a principal meeting place linking all the rooms surrounding it, including the reception hall and the main entrance.

\section{The TETRASTYLOS (HH13, HH26)}

The second courtyard (HH13, HH26) of the 'Hellenistic' House was situated in the western part of the residence (Figs 3, 6-7, 9) and designed as practically square: $10.15 \mathrm{~m}$ (E-W) by $9.8 \mathrm{~m}(\mathrm{~N}-\mathrm{S})$. During archaeological works uncovering the courtyard the perimeter walls were not the only parts excavated, but also an impluvium and many fragments of architectural decoration and pieces of structural elements, which, just as in case of the peristyle, permitted reconstructing the form of the courtyard in question.

The impluvium located in the centre of the courtyard corresponded to its shape: it was also almost square with a side around $3 \mathrm{~m}$ wide, leaving free space of equal width all around. The basin was bordered with low wide stone slabs, one of which is visible in the south-western corner (Fig. 7). A hydraulic floor with a pipe outlet was installed inside the pool several centimetres below the level of the courtyard. ${ }^{43}$

Four columns were erected in the corners of the impluvium, four bases of which have survived in situ and two drums of a shaft with a capital were found lying outside the basin, in the north-western corner of the courtyard. Two drums of the north-western column created the lower part of a smooth shaft with at least one drum missing. The shaft was characterised by slight convergence. ${ }^{44}$

The capital of the column that was found next to the drums is a pseudo-Ionic blocked-out capital, derivative of the Ionic order. So far, it is the only known example of such a type on Cyprus and very rare in the Eastern Mediterranean. The best examples of such capitals are known from the Deir and the Palace Tomb from Petra, although there are minor differences between the Cypriot capital and its counterparts from Nabataea. ${ }^{45}$

Analysis of the preserved parts of the column allowed Henryk Meyza to estimate its height at almost $4 \mathrm{~m}$. Such a height and the proportions of the Paphian column in comparison with

${ }^{41}$ Karageorghis 1988: 837; Meyza 2015: 444-445.

${ }^{42}$ Daszewski 1994: 103-104; Meyza et al. 2017.

${ }^{43}$ Brzozowska-Jawornicka 2019: 57-60; Meyza et al. 2012: 413-414.

44 Brzozowska-Jawornicka 2019: 60; Meyza et al. 2012: 413-414.

45 Brzozowska 2016; Brzozowska-Jawornicka 2019: 60; McKenzie 1990: 100-102, 117, 160, 162-164, 167, 184; 2001: 100-102; Meyza et al. 2012: 413. 


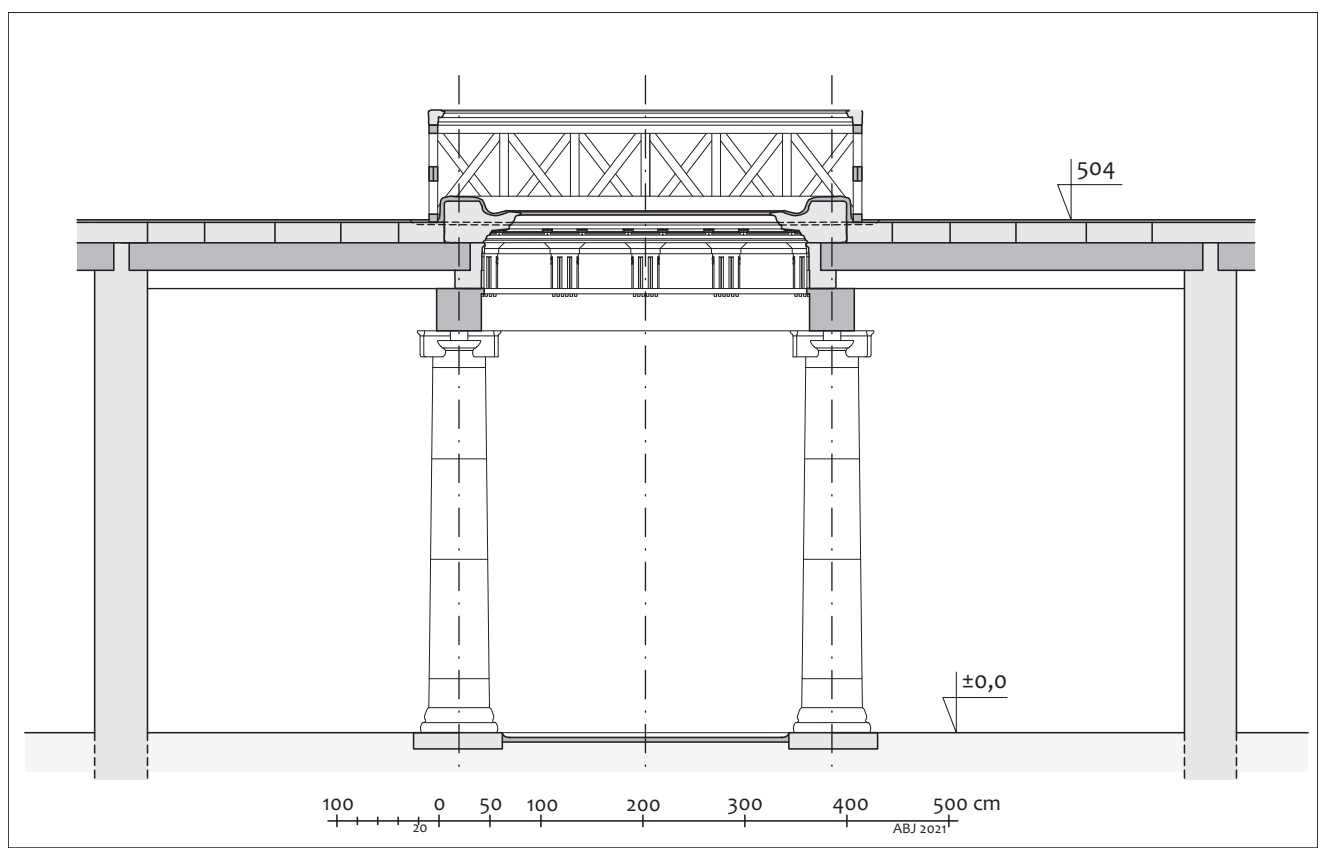

6. Tetrastylos of the 'Hellenistic’ House: theoretical reconstruction (Drawing: A. Brzozowska-Jawornicka).

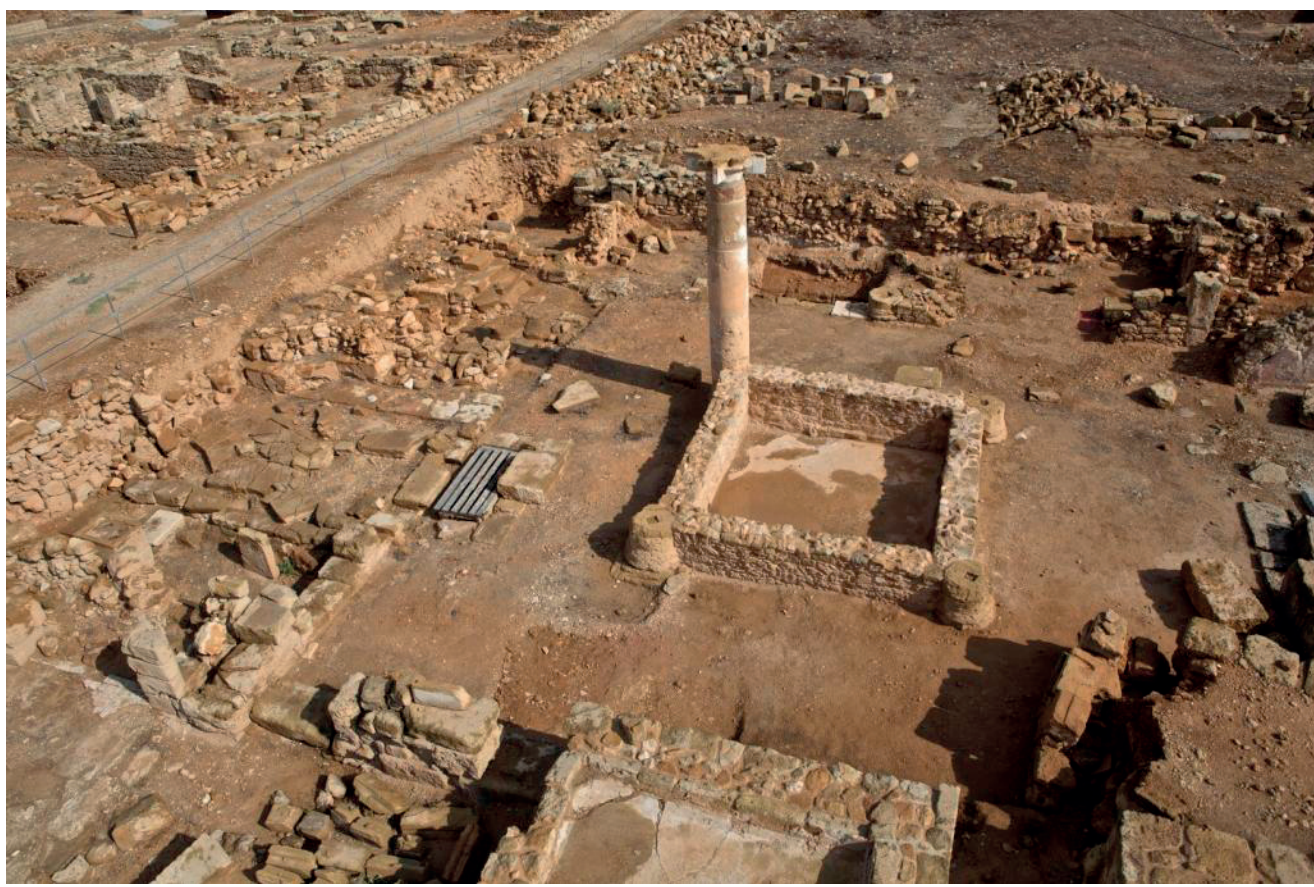

7. Tetrastylos of the ‘Hellenistic’ House: remains of the impluvium with one column (Phot. A. Brzozowska-Jawornicka). 
a classical Ionic column or the Nabataean columns crowned with pseudo-Ionic blocked-out capitals makes the Paphian column rather squat. ${ }^{46}$

Apart from the fragments of the column, a set of other construction elements belonging to the same architectural ensemble was excavated in the western courtyard. It contained: blocks of a simplified Doric frieze, fragments of a crowning cornice and pieces of small cornices. Unfortunately, all these blocks were in a poor state of preservation.

Nine blocks of frieze embellished with triglyphs and plain metopes were preserved, none of them was a corner block. ${ }^{47}$ The design of the frieze differs slightly from the classical canon, ${ }^{48}$ e.g. the bottom of the frieze is terminated with a sharp edge. The lowest part of the frieze decoration could have been shifted to the architraves, but this cannot be confirmed as no fragments of architraves were excavated. However, such a solution is highly probable as there are many analogies known from the Eastern Mediterranean. ${ }^{49}$

The blocks of frieze were not only decorative, but primarily constituted structural elements of the upper storey ceiling as cuboid sockets were carved in their back upper part. They were originally supporting unpreserved wooden ceiling beams.

Eleven fragments of the Corinthianising crowning cornice, including two inner corners with crossed decoration, were also found in the vicinity of the impluvium. They were decorated with flat grooved modillions alternating with square hollow ones. Such decoration constitutes an example typical of the already mentioned Alexandrian style, very popular across the entire Eastern Mediterranean. ${ }^{50}$

Just like the frieze blocks, the elements of the cornice were not only decorative, but had also a utilitarian function: a sima, i.e. a gutter for rainwater, was carved in their outer surface. Two corner blocks were also equipped with outlets designed to convey water from the gutter. The cornice with the sima was covered with a thick layer of hydraulic mortar.

Forty fragments of small cornices including four inner corners constituted the last part of the architectural embellishment from the western courtyard. As their upper surface is smooth and slightly convex, they may have served as a handrail of a balustrade.

Apart from pieces of architectural decoration, massive stone slabs were excavated around the impluvium.

A detailed analysis of the western courtyard layout, as well as all the blocks found there, permitted a reconstruction of its structure..$^{51}$ It seems that the courtyard was an atrium with

46 Brzozowska-Jawornicka 2019: 64-66.

47 Meyza et al. 2012: 414.

48 Vitr., De arch. IV.2.

49 McKenzie 2001: 103-105; 2007: 58, Fig. 74; 65, Figs 91, 94b; Pensabene 1993: Pls 2.9, 9.62-63, 99.949; Stucchi 1975: 204, Fig. 195; Vanderstar 1997: Pls DC3-4, DA2, DF1, MK3, DA1, DF2, DF3; Wright 1992: 47, Fig. 2.

50 McKenzie 1990: 93-94; 2007: 87-89, Figs 139-140; Meyza et al. 2012: 414; Pensabene 1993: 99-103, Pls 6.33-34, 92-99, 101.960-965, 131-133, 135.

51 Brzozowska-Jawornicka 2019. 
four columns supporting the ceiling of the upper storey. Such a form - called by Vitruvius a tetrastylos - was common in residences of the Graeco-Roman world. It usually had an impluvium collecting water in the middle and a compluvium above it which let in light and rainwater. All the features are present in the western courtyard of the 'Hellenistic' House, although with some differences, e.g. its plan was square, not rectangular. ${ }^{52}$

The tetrastylos was composed of four columns crowned with pseudo-Ionic blocked-out capitals which were carrying unpreserved wooden architraves, a simplified Doric frieze and a Corinthianising cornice. Such an arrangement mixing elements of different architectural orders in one architectural ensemble is another feature typical of the Alexandrian style. ${ }^{53}$

The entablature resting on the columns served as a support for the ceiling used as a utilitarian terrace. Its construction was composed of unpreserved wooden beams which were supported by the perimeter walls of the courtyard on the outer side and the frieze blocks on the inner side of the atrium. The massive stone slabs were resting on the beams. Covered with hydraulic mortar they created a waterproof floor of the terrace. The compluvium was protected by an unpreserved wooden balustrade with a stone handrail made of small cornices. The rainwater from the terrace was collected by the gutter and directed to the impluvium and possibly to other water tanks placed in the area of the Western Courtyard. ${ }^{54}$

Two staircases provided access to the terrace located on the second storey: the first situated next to the north-western corner of the atrium (HH28N) and the second on its opposite side beside the south-eastern corner (HH11). Traces of several doors are visible in the perimeter walls of the courtyard proving that it was linked with the adjacent rooms (described below), providing them with air and serving as a light-well, an arrangement typical of a Roman house. ${ }^{55}$

In a Roman house an atrium was usually connected to a vestibule and a gate linking a residence 'for men of rank', as Vitruvius wrote, ${ }^{56}$ with a street. Since the western courtyard is placed near the corner of streets 10 and A', it seems reasonable to assume that another entrance to the 'Hellenistic' House was in one of the rooms situated south and east of the courtyard, perhaps using the staircase situated in room $28 \mathrm{~N}$ described below. So far, this assumption has not been confirmed by archaeological evidence, although, firstly, the research is not yet finished, and secondly, the western part of the residence, just like the rest of the 'Hellenistic' House, was severely ruined, which may distort reconstruction of its functional and spatial arrangement.

${ }^{52}$ Vitr., De arch. VI.3.1. Square atria in a tetrastylos form were often designed in the eastern Roman provinces, e.g. in Greece (Papaioannou 2010: 90, 112, Fig. 33).

${ }^{53}$ McKenzie 1990: 93-94; 2007: 87-89, Figs 139-140; Pensabene 1993: 99-103, Pls 6.33-34, 92-99, 101.960-965, 131-133, 135. The strong Alexandrian influence was also confirmed by the metrological studies which proved that not only artistic traditions originated in the Ptolemaic Egypt were present in the 'Hellenistic' House, but also the Ptolemaic system of measures was used to design the residence (Brzozowska-Jawornicka, Kubicka-Sowińska 2021).

${ }^{54}$ Daszewski 1992a: 64-65; Meyza et al. 2012: 412-413.

${ }^{55}$ Ellis 2000: 136-137; Wallace-Hadrill 1997: 231.

${ }^{56}$ Vitr., De arch. VI.5.2-3. 
Courtyards similar to the tetrastylos from the 'Hellenistic' House can be found, among other places, in numerous Roman houses in Greece, e.g. 'Villa' Romana in Corinth, ${ }^{57}$ although usually they were not crowned with a utilitarian terrace on the upper floor. Many of them served as a vestibule or a reception area connected with an entrance to a residence (e.g. in the 'Palace of Nero' at Olympia), ${ }^{58}$ which also confirms, indirectly, a possible gate located next to the tetrastylos of the 'Hellenistic' House.

\section{THE EASTERN COURTYARDS (HH8E AND HH30)}

In the south-eastern corner of the 'Hellenistic' House, almost next to its eastern border wall, a small courtyard (HH8E) was designed in the form of oblong rectangular open space (around $6.5 \mathrm{~m}$ from west to east, and $2.6 \mathrm{~m}$ from north to south) preceded on the south-west side by a smaller rectangular compartment (HH8S; Figs 3, 8, 10). The latter directly borders street A' and probably served as a vestibule since in its southern wall traces of a wide threshold were found, a part of an entrance leading from the street. ${ }^{59}$

The small courtyard was paved with a pebble floor set in lime mortar, in some spots replaced by irregular marble slabs. This open area without any special architectural decoration provided access to several adjacent rooms in the north and east, what is proved by mortises for wooden door jambs in its walls. ${ }^{60}$

The vestibule (HH8S), placed between the courtyard $8 \mathrm{E}$ and street $\mathrm{A}^{\prime}$ was divided into two parts. The eastern, larger one took the form of a ramp situated on the axis of the door leading to the street. The ramp enabled descending from the higher level of the street to the courtyard located about $0.5 \mathrm{~m}$ below. ${ }^{61}$ The western side of the vestibule, bordering with a big latrine (HH8), constituted a narrow passage with a channel and remains of seats, apparently serving as a small toilet. ${ }^{62}$

Room 30 (Figs 3, 8) was almost completely destroyed by the southern part of the great hall of the Villa of Theseus (VT39). Its identification as a north-eastern courtyard seems to be corroborated by the layout of that part of the 'Hellenistic' House: it provided light, air and access to rooms situated there, both those excavated and those completely damaged in the north-eastern part of residence.

Judging by the lack of any architectural embellishment, except for the pebble floor set in lime mortar, the eastern courtyards must have served purely domestic use providing light and air to the rooms distributed around and in the case of the south-eastern courtyard (HH8E) linking the eastern part of the 'Hellenistic' House with street A'.

\footnotetext{
57 Bonini 2006: 56-59, 318-319.

58 Papaioannou 2010: 92.

59 Meyza et al. 2011: 291-293; 2014: 400.

${ }^{60}$ Daszewski 1996: 93-95; 1997: 115-117; 1998: 123-124; Meyza et al. 2011: 291-293.

61 Daszewski 1996, 93-95; 1997: 113-115; 1998: 123.

62 Daszewski 1996: 95.
} 


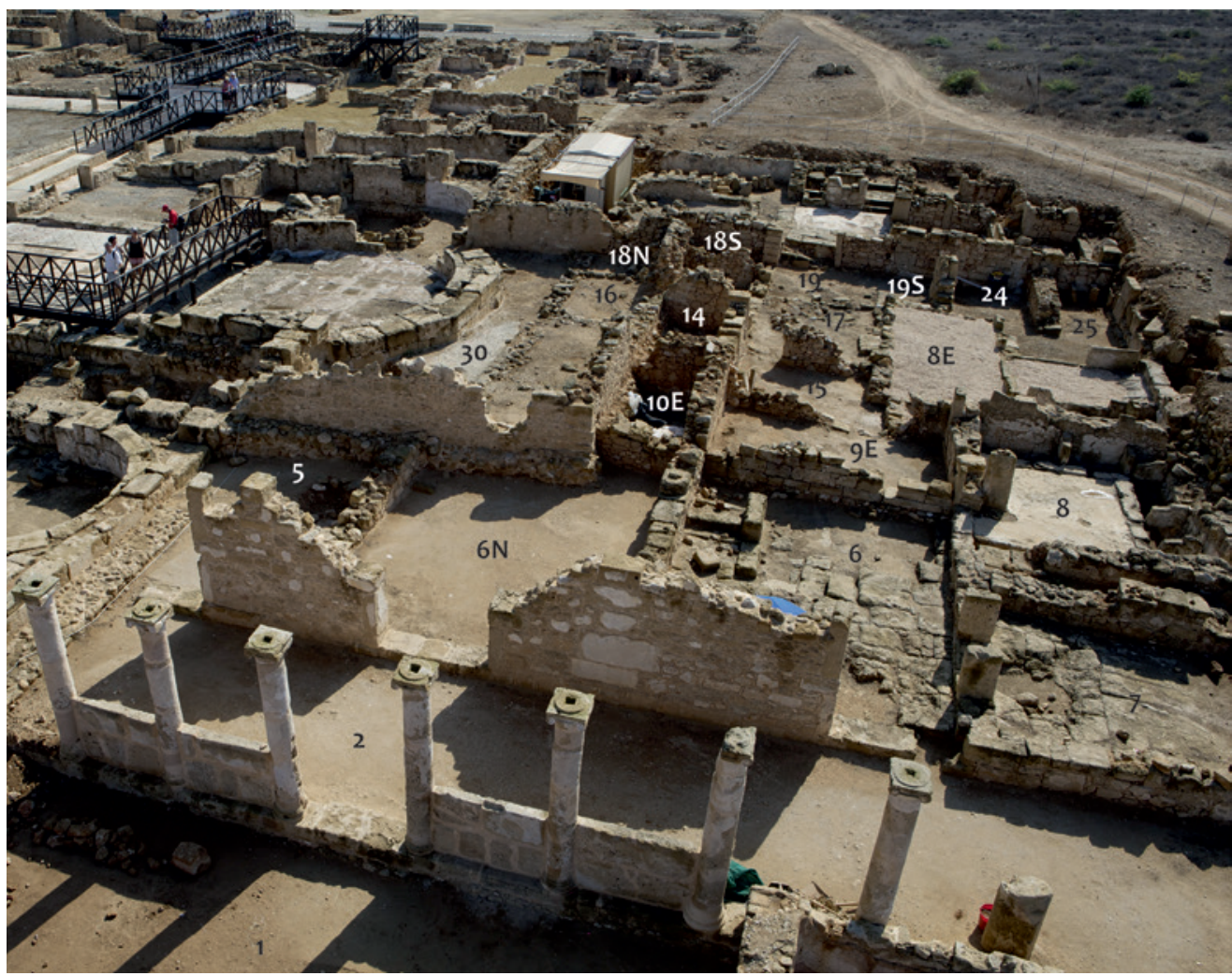

8. Relics of the 'Hellenistic’ House: eastern part (Phot. M. Jawornicki).

ROOMS AND COMPARTMENTS (HH5-12, HH14-25, HH27-28, HH31-33)

In the eastern half of the 'Hellenistic' House (Figs 3, 8) communication between rooms was enabled by three courtyards: the main one (HH1), specifically its eastern portico (HH2) and northern pseudo-portico (unpreserved), and the two eastern courtyards, the north-eastern (HH30) and the south-eastern (HH8E).

Four large rooms (HH5, 6N, 6 and 7) were designed behind the preserved part of the Ionic portico. Remains of painted plaster decoration were uncovered on walls of rooms 5 and $6 \mathrm{~N} .{ }^{63}$ The considerable size and location of these rooms next to the Main Courtyard of the residence, as well as richly decorated interior suggest that they had rather an official function. ${ }^{64}$

63 Daszewski 1991: 82-83; 1995: 67-69; 1999: 163; Daszewski et al. 2008: 511; Karageorghis 1987: 683; 1988: 837.

${ }^{64}$ Daszewski 1999: 163-165. 
Two southern rooms (HH6 and HH7) were paved with large rectangular slabs sealed with waterproof mortar and their walls were plastered. Remains of a possible staircase were preserved next to the north-eastern wall of room 6. It could have provided access to the second storey of the eastern part of the 'Hellenistic' House. Cisterns and water installations uncovered in rooms 6 and 7 prove that the rooms in question may have served as washrooms or a laundry, the more so as a latrine (HH8) lies next to them (Figs 8, 10). The size of a presumed washrooms/laundry indicates that it was designed for at least ten users at a time, ${ }^{65}$ probably for residents of the 'Hellenistic' House and their guests gathered within the Main Courtyard.

Between the rooms directly bordering the Ionic portico and two eastern courtyards, two rows (W-E) of rooms were situated (HH10E, 14, 16, 18N 18S and, HH9E, 15, 17, 19, 19S) with floors made of tamped earth mixed with lime. The rooms next to the Ionic portico and those to the east of them were connected by at least one, although a surprisingly narrow, door linking rooms $9 \mathrm{E}$ and $6 .{ }^{66}$ The bigger rooms 10E, 14, 16 and 18, subdivided by the so-called Byzantine wall, were adjacent to the north-eastern courtyard (HH30) and the smaller ones, 9E, 15, 17 and 19, bordered with the south-eastern courtyard (HH8E). The two rows of rooms were also linked by doors. ${ }^{67}$ A sort of a passage (HH19S) and room 24 led from room $8 \mathrm{E}$ eastward. ${ }^{68}$ A stone table excavated in room 25 proves that the eastern side of the House had a domestic character. ${ }^{69}$

In the western part of the 'Hellenistic' House (Figs 3, 9) rooms were organised between the western portico (HH4) and the northern pseudo-portico (unpreserved) of the peristyle (HH1), as well as around the tetrastylos (HH13, HH26) and a corridor (HH29).

The reception hall (HH10), situated behind the western portico of the Main Courtyard, was the biggest and the most important room in the whole residence. Its design followed the majority of the Vitruvian rules: as a room where the owner of the residence hosted his official guests, the reception hall must have been properly arranged and equipped to underline the social position of the family. The room was rectangular with a longer east-west axis. As suggested above, the Main Courtyard was organised around the same axis, so we can assume that they were designed as a harmonious and complete composition. Therefore, it seems logical that the entrance to the reception hall situated in the middle of its shorter side should have been emphasised by an appropriate architectural frame, e.g. a widening of the central span in the portico situated on the same axis. Unfortunately, due to the poor state of preservation it is impossible to verify this assumption. On the other hand, the importance and rank of the reception hall was clearly underlined by the form and scale of the preceding portico: the Corinthian portico, the highest and the most decorative of the

65 Daszewski 1990: 35; 1991: 82-83; 1992a: 66; 1995: 69; 1996: 93; 1999: 163-167; Papageorghiou 1990: 975.

66 Daszewski 1999: 167; Daszewski et al. 2007: 403-405.

67 Daszewski et al. 2007: 405.

${ }^{68}$ Daszewski 1998: 124.

${ }^{69}$ Meyza et al. 2011: 291-293. 


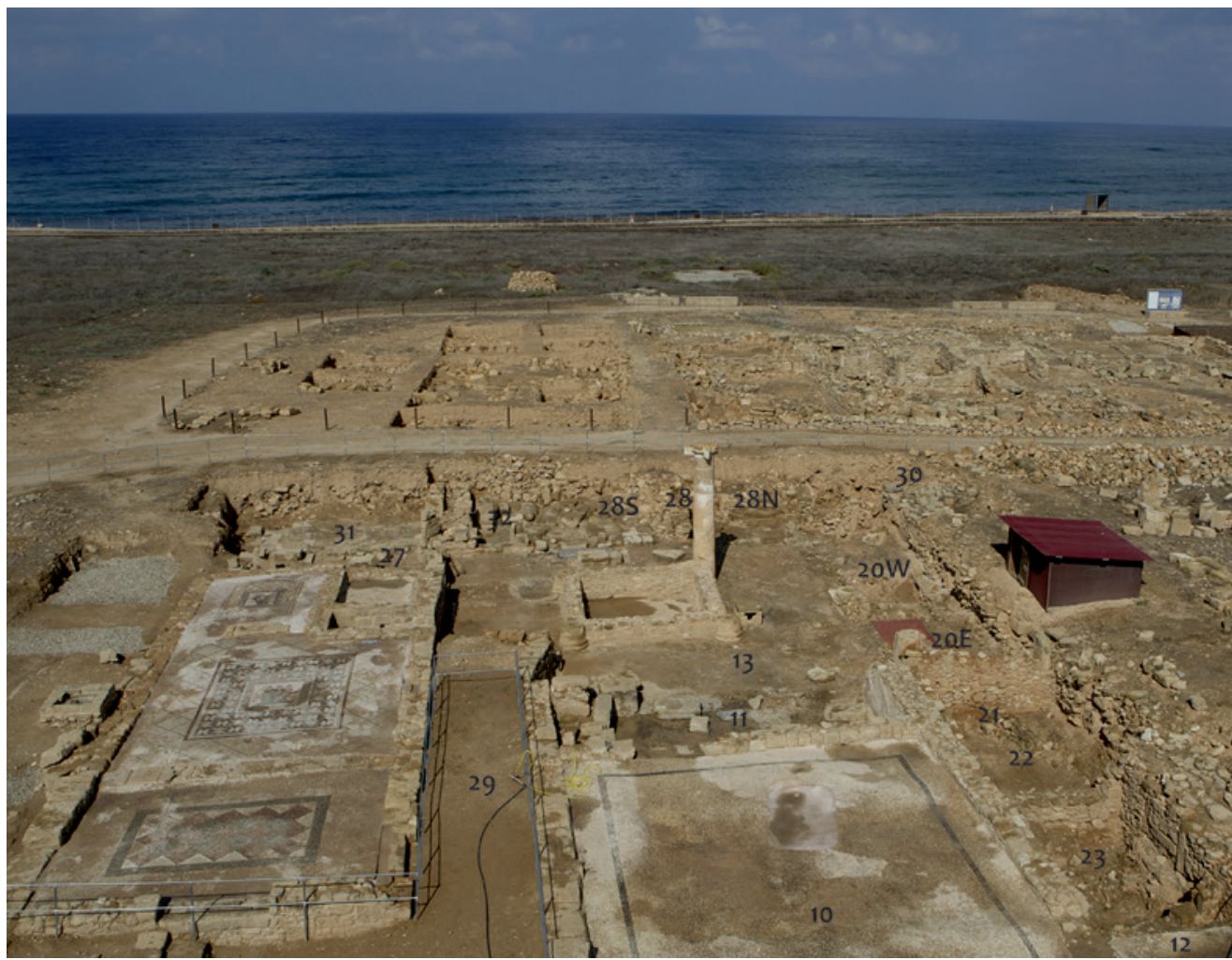

9. Relics of the 'Hellenistic’ House: western part (Phot. M. Jawornicki).

entire residence. The interior of the reception hall was richly decorated with wall-paintings characterised by intense colours and a white mosaic-floor of irregular fragments of pebbles surrounded by a black border, ${ }^{70}$ perhaps similar to the magnificent Room B at the Terrace House I in Ephesus. ${ }^{71}$

A smaller room (HH12), with a lime mortar floor, was uncovered north of the reception hall. Although its northern side was completely destroyed, ${ }^{72}$ it seems likely that it was opened towards the western portico. Along the southern wall of the reception hall (HH10), a long corridor (HH29) was designed providing access to rooms on its northern (HH10 and HH11) and southern side (HH9, HH9W and RH3, RH1 and RH2). The latter were damaged or at

70 Daszewski 1990b: 35; 1991: 83-84; 1992: 253; 1993: 88; Papageorghiou 1990: 975-977. The wall paintings and the mosaic were analysed by Wiktor A. Daszewski shortly after their discovery when the newly uncovered residence was dated to the Hellenistic period. At that time it seemed logical that the decoration of the House resembled the first style of the Pompeian painting. Afterwards no one continued Daszewski's studies or questioned his conclusions, although in the light of the new dating of the 'Hellenistic' House a re-analysis of the wall-paintings and mosaics would certainly be advisable.

71 Gros 2006: 221, Fig. 247.

72 Daszewski 1992a: 64. 


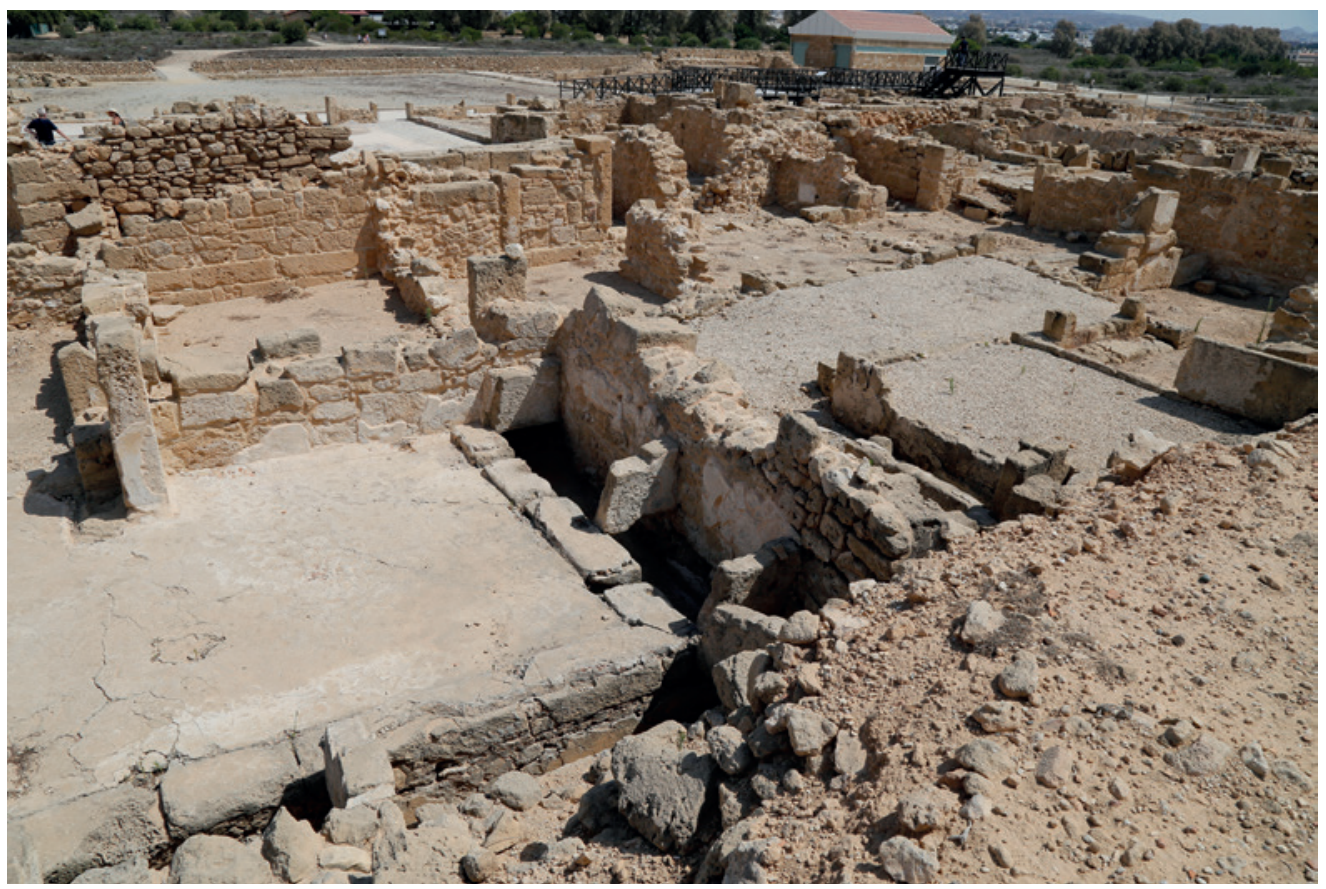

10. Relics of the 'Hellenistic' House: eastern part - latrine (HH8) and entrance (HH8S) (Phot. A. BrzozowskaJawornicka).

least covered by the later Roman House, erected there after the destruction of the 'Hellenistic' House. However, it seems that the layout of the younger building followed the plan of the older one. Therefore, a row of rooms stretching between street A' and corridor 29 with an access from the side of the latter, could be reconstructed in this part of 'Hellenistic' House. On its western end the corridor reaches the south-eastern corner of the tetrastylos (HH13, HH26). The western end of the Roman House, covering the original rooms of the 'Hellenistic' House, stretched along the southern side of the tetrastylos. Its layout, composed of rooms 2 and 4, most probably duplicated the older structures, although the relation between the two houses requires further studies. ${ }^{73}$

The most elaborate wall-paintings of the entire 'Hellenistic' House, executed in the al secco technique and very colourful, were found in room 11, which lies between the reception hall and the tetrastylos. Such rich paintings emphasize a significant role of this room in 'Hellenistic' House. Room 11 and tetrastylos were linked by a wide door. The floors of the whole western part of the 'Hellenistic' House, starting with room 11 in the east (including the tetrastylos with the adjacent rooms), lies around $0.8 \mathrm{~m}$ below the level of the

${ }^{73}$ Daszewski 1994: 108-109; Meyza et al. 2012: 416-418. However, due to the poor state of preservation of the relics and problems with continuation of the archaeological works next to a path for tourists, the exact relation in time between the 'Hellenistic' House and the Roman house may never be established. 
floors of the rest of the residence. The already mentioned staircase in room 11 could have linked two storeys: the level of tetrastylos $(-0.8 \mathrm{~m})$ with the level of the Main Courtyard and the eastern side of the House $(0.00 \mathrm{~m})$, and even the third storey - the terrace above the atrium $(+4.24 \mathrm{~m})$.

A row of several rooms (HH33, HH20W, HH20E, HH21, HH22, HH23) was designed north of the tetrastylos, room 11 and the reception hall (HH10). The rooms, which were joined by the doors most probably served as another domestic part of the edifice, as remains of a table with a deposit of kitchen vessels were found there. ${ }^{74}$ Although their northern side is completely damaged by the southern wall of the Villa of Theseus, it was established that the level of their floors was similar to that of the tetrastylos, ${ }^{75}$ with which they were connected. ${ }^{76}$ The remains of another possible staircase, a narrow one, were found leaning against the southern wall of room $33 .{ }^{77}$

The western limits of the 'Hellenistic' House were closed with a north-south oriented row of rooms (HH33, HH28N, HH28S, HH32 and HH31), stretching between the tetrastylos and street 10 . In the south-eastern corner of insula, in room 4 of the Roman House and rooms 27 and 31 of the 'Hellenistic' House, the remains of a hypocaust with a channel for gases were uncovered (Fig. 11). Room 32 was identified as a praefurnium, although no clear traces of a furnace were found. ${ }^{78}$ Unfortunately, the very poor state of preservation of the hypocaust system, i.e. almost entirely robbed out walls and only partly preserved terracotta tiles of the heating space floor, makes the reconstruction of the complete heating system, as well as the connections between particular rooms, very difficult at the present state of research. ${ }^{79}$ However, the remains testify that terms must have been built in this spot. Their relationship with the buildings, especially with the 'Hellenistic' House is presently unclear.

In the area of compartments numbered 28N, 28 and 28S remains of a very interesting staircase were uncovered (Fig. 12). It seems that the stairs, mentioned already in the description of tetrastylos above, were designed in three flights rising up from the level of the tetrastylos and reaching the terrace above it. They started in the northern side of room $28 \mathrm{~N}$ ascending from east to west with five steps to reach the first (unpreserved) landing in the north-western corner of the room. Then the next flight of the north-south middle course of the stairs rose parallel to the adjacent external wall of the room, thereby the western outer wall of the whole residence, reaching the second (also unpreserved) landing. Two steps of the middle flight were found loose. One of these platforms could also have served as a vestibule with an entrance linking the western courtyard with street 10 , but there is no clear archaeological evidence of its presence. The third and most

\footnotetext{
${ }^{74}$ Więch 2017: 446.

75 Daszewski et al. 2010: 509-511.

76 Więch 2017: 440.

77 Daszewski et al. 2010: 511-512; Meyza et al. 2012: 418; 2014: 399.

78 Meyza et al. 2012: 416-418.

79 Daszewski 1994: 108-109; 1995: 72; Meyza et al. 2012: 416-418; 2014: 393-397.
} 


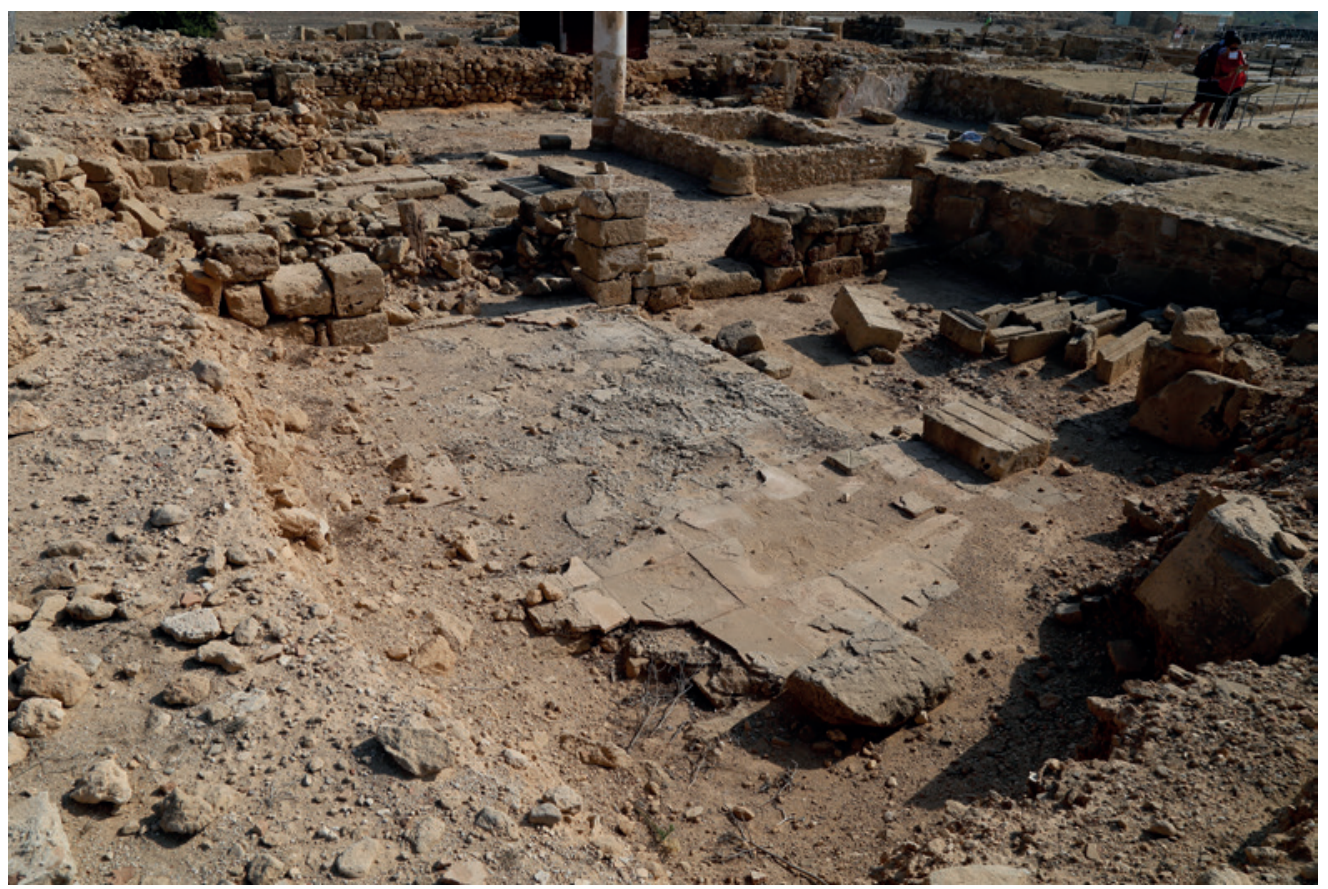

11. Relics of the 'Hellenistic' House: western part - hypocaust system (HH27, HH31, RH4) (Phot. A. BrzozowskaJawornicka).

probably the final flight of the staircase must have changed its course once again to the west-east direction rising east along the southern wall of room 28 and leading to the terrace above the tetrastylos. ${ }^{80}$

\section{FIRST STOREY}

The relics of many staircases were discovered in the eastern and western parts of the 'Hellenistic' House, proving that the first floor was erected on both sides of the residence's Main Courtyard (Fig. 3). It seems that some galleries were designed above the Doric and Ionic porticoes of the peristyle, the eastern one leading to rooms placed further east and accessible by the stairs in room 6 . The storey above the southern portico was single-bay, as behind the gallery there was a wall constituting the southern elevation of the residence next to street A'. The western part of the residence, especially the area of the tetrastylos was roofed with a utility terrace reachable by at least two staircases, one in room 11, second in rooms 28N and 28 (Fig. 12). It is not clear, if the two upper storeys located on both sides of the peristyle were connected - the gallery above the southern portico may be an

\footnotetext{
${ }^{80}$ Meyza et al. 2014: 397-399.
} 


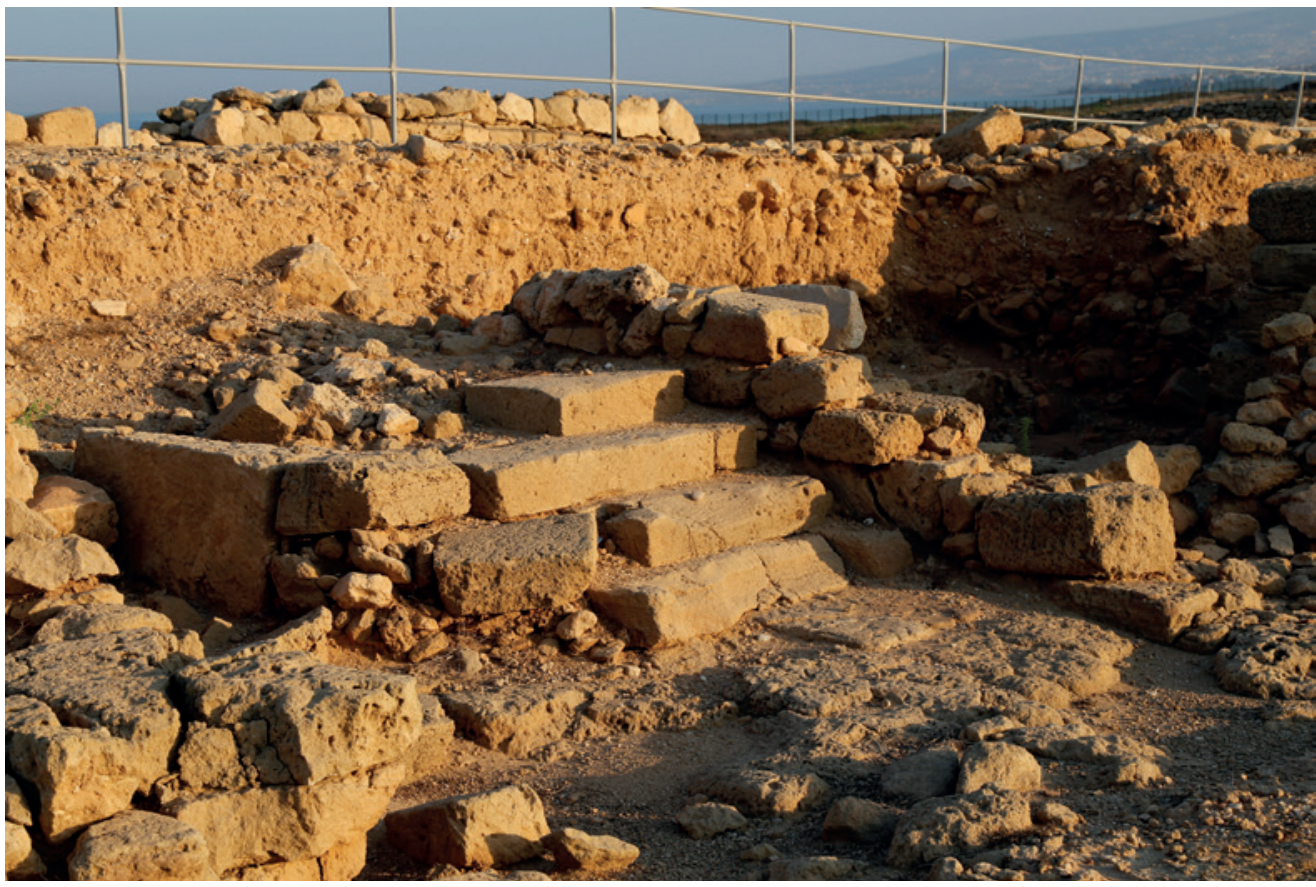

12. Relics of the 'Hellenistic’ House: western part - staircase (HH28-28N) (Phot. A. Brzozowska-Jawornicka).

indirect proof of such an arrangement. Its northern equivalent behind the pseudo-portico, as the whole northern part of the House, remains unknown.

\section{DeSTROYED NORTHERn PART OF THE 'Hellenistic' House}

As has already been emphasised many times, about one third of the 'Hellenistic' House area was irreversibly destroyed during erection of the Villa of Theseus. Only small fragments of the 'Hellenistic' House's foundations were discovered below the floors and between the foundations of the Villa. ${ }^{81}$ An attempt to reconstruct the layout of the House on the above-mentioned basis is highly error-prone and may lead to false conclusions. The only, so far unexcavated, area which may bring new information about the northern part of the 'Hellenistic' House is the north-western corner of the insula in question (between streets A and 10), where a back courtyard of the Villa of Theseus was located. It was left open and empty, hence the conclusion that it served as a garden, and there were no constructions that would have destroyed relics of older buildings lying below, specifically the 'Hellenistic' House.

${ }^{81}$ Daszewski 1995: 69-72, Fig. 2; Daszewski et al. 2007: 403; 2008: 511. 


\section{BUILDING MATERIALS AND TECHNIQUES}

The 'Hellenistic' House was built of blocks obtained in local Paphian quarries of calcarenite. Such a stone is characterised by weak durability and great absorbency, ${ }^{82}$ which contributed to the rapid erosion and deterioration of the blocks and consequently was one of the causes of the destruction of the residence. The ancient builders were aware of the poor quality of the building materials and covered the walls with plaster, sometimes painted, or elements of architectural decoration with whitewash to strengthen and protect their surface.

The structure of the residence walls varies: from massive ashlar constructions bonded with lime mortar to small irregular stones connected with earth mortar. Some parts of the walls were erected in the opus africanum/incertum technique. ${ }^{83}$ The foundations also consisted of small irregular stones that were usually bound with earth mortar although traces of gypsum mortar are also present. They were usually made in the fill-in type in narrow foundation trenches. Sometimes the foundations were surprisingly shallow and because of that, also weak, as in the case of the stylobate of the western portico of the Main Courtyard. ${ }^{84}$

The columns were composed of bases, shafts made of drums of various height, and capitals. Like the walls, they were plastered and, in the case of the Corinthian portico, painted with bright colours.

No traces of vaults were found in the 'Hellenistic' House. The structural partitions of the residence storeys must have been flat and most probably made of wood - the cuboid sockets for the unpreserved wooden ceiling beams carved in the frieze blocks from the tetrastylos constitute an indirect proof of such a construction, which most probably was widely used in the whole residence.

The remains of stair-cases reveal that their construction was made of massive stone blocks supported by walls.

The house roof had probably also a wooden structure and was covered with ceramic tiles, although, due to the lack of any traces, it is only a supposition.

As mentioned above, there were several types of floors in the residence: from floors made of tamped earth mixed with lime or clay through a pebble floor set in lime mortar to a mosaic of irregular fragments of pebbles.

\section{WATER INSTALLATIONS}

The remains of a complex system of water installations including horizontal and vertical pipes, settling tanks, basins and reservoirs were discovered all over the 'Hellenistic'

\footnotetext{
${ }^{82}$ Calcareous conglomerate, $2.6 \mathrm{~g} / \mathrm{cm}^{3}$, with grains of c. $2-0.1 \mathrm{~mm}$, of a structure resembling sandstone. Information obtained from a geologist, Michalina Dzwoniarek-Konieczna.

83 Meyza 2015: 444-445.

${ }^{84}$ Daszewski 1991: 83; Meyza et al. 2014: 400; 2017: 399-401.
} 
House and under the streets surrounding it. ${ }^{85}$ It seems that water was collected from the entire surface of the House's roofs and courtyards, directed by gutters and downpipes or gargoyles to open basins or underground cisterns to be stored and used, especially during hot and dry summers. Large quantity of water-tanks prove the great need to accumulate and store water brought by aqueducts ${ }^{86}$ and rainwater in the residence due to the lack of drinking water sources in the Maloutena region.

\section{‘HELLENISTIC’ HOUSE IN A WIDER CONTEXT AND CONCLUSIONS}

Although the study of the 'Hellenistic' House is not yet completed and the residence itself is not fully preserved, it is possible to point out some of its basic features and to indicate further directions of research concerning its architecture.

The 'Hellenistic' House was an urban mansion embedded in the Roman as well as the Greek and the Near Eastern tradition. In the eastern provinces of the Roman Empire, rich and luxurious townhouses were often called villas, unlike in Italy and in the western provinces, where this term meant a farm. Such luxury town-residences of the eastern elite with architectural features typical for the rich Graeco-Roman houses, e.g. triclinia, mosaics or peristyles are known from e.g. Zeugma, Sepphoris or Tiberias ${ }^{87}$ In these terms the 'Hellenistic' House fits into the eastern understanding of the concept of the villa.

This large edifice was designed around several courtyards - a typical layout of a GraecoRoman rich house. ${ }^{88}$ It bore traces of the artistic influences of all the major cultures of the Eastern Mediterranean at the turn of the eras: the Greeks, the Near East, the Ptolemaic Egypt and the Romans, especially the so-called Alexandrian style. Considering the preserved relics of the residence's architecture, the Main Courtyard arranged as a unique Rhodian pseudoperistyle, the western courtyard designed as a tetrastylos and the extravagant architectural decoration are the most interesting fields of research. Analogies of such a combination of a tetrastylos and a peristyle (or a peristyle garden) in one residence are known from the eastern provinces of the Roman Empire, e.g. the Terrace House I in Ephesus, ${ }^{89}$ or the house at Patras, ${ }^{90}$ and prove the wealth and prestige of their inhabitants. The same phenomenon occurs with the 'Hellenistic' House, whose layout and architectural decoration confirm the social and political status of the residence owner and his attachment to the Graeco-Roman style of life.

The exact function of the particular rooms of the 'Hellenistic' House is, with a few exceptions, very difficult to establish. Firstly, damage caused by an earthquake and in consequence abandonment of the 'Hellenistic' House by its residents, robbing out not only

${ }^{85}$ Daszewski 1992a: 65; 1996: 92-93; Daszewski et al. 2010: 511; Meyza et al. 2012: 415-416; 2017: 401-412; Meyza 2015: 449-450; Romaniuk 2021. The water installations from the Maloutena area including those from the 'Hellenistic' House are the subject of Marcin Romaniuk research.

${ }^{86}$ Romaniuk 2021: 387-389, 392.

${ }^{87}$ Rothe 2018: 51; Weiss 2018: 317.

${ }^{88}$ Gros 2006: 214.

${ }^{89}$ Gros 2006: 220.

${ }^{90}$ Papaioannou 2010: 90-91. 
the residence equipment, but even the structural elements like walls, blocks or pieces of architectural embellishment, and finally the construction of later edifices changed permanently the House and that is why some information is irretrievably lost. Secondly, according to recent research ${ }^{91}$ rooms in the Graeco-Roman residences were usually multifunctional and arranged according to the wishes and needs of their residents. The precise and strict plan of a typical ancient house presented e.g. in the Vitruvian treatise was rather an indication or an idea that was pursued but seldom achieved. Personal preferences as well as local traditions and possibilities were far more important.

So far, about thirty rooms of the 'Hellenistic' House have been uncovered, but the excavations of the residence and research on its architecture are not yet over. Therefore, the exact number of the rooms and their function as well as the spatial arrangement of the whole House should be verified, deepened and supplemented with continuous studies.

\section{Acknowledgements}

The author has been working for the Polish Archaeological Mission since 2005. I would like to thank the directors of the Mission, Henryk Meyza and Ewdoksia Papuci-Władyka, for supporting me in many studies of the ancient Cypriot architecture.

\section{References}

Bonini, P. 2006: La casa nella Grecia romana: forme e funzioni dello spazio privato fra I e VI secolo, Roma

Brzozowska, A. 2016: A Pseudo-Ionic Blocked-Out Capital at Nea Paphos, EtudTrav XXIX, 43-65

Brzozowska-Jawornicka, A. 2019: Reconstruction of the Western Courtyard of the 'Hellenistic' House, in Nea Paphos, Cyprus, [in:] Bąkowska-Czerner, G., Czerner, R. (Eds), Greco-Roman Cities at the Crossroads of Cultures. The $20^{\text {th }}$ Anniversary of PolishEgyptian Conservation Mission Marina el-Alamein, Oxford, 57-73

Brzozowska-Jawornicka, A. forthcoming: The architectural orders and decoration of the 'Hellenistic' House, [in:] Balandier, C., Michaelides, D., Raptou, E. (Eds), Nea Paphos and Western Cyprus, Bordeaux

Brzozowska-Jawornicka, A., Kubicka-Sowińska, A. 2021: In Search of the Module in the Architectural Design of the 'Hellenistic' House in Nea Paphos, Cyprus, EtudTrav XXXIV, 123-140

Daszewski, W.A. 1985: Researches at Nea Paphos 1965-1984, [in:] Karageorghis, V. (Ed.), Archaeology in Cyprus 1960-1985, Nicosia, 277-291

Daszewski, W.A. 1990: Nea Paphos 1989, PAM I, 35-36

Daszewski, W.A. 1991: Nea Paphos 1990 Report, PAM II, 78-84

Daszewski, W.A. 1992a: Nea Paphos 1991, PAM III, 59-67

Daszewski, W.A. 1992b: Nea Paphos 1991, RDAC 1992, 251-254

${ }^{91}$ Hales 2003: 126-147 with indications to further literature. 
Daszewski, W.A. 1993: Nea Paphos 1992, PAM IV, 83-93

Daszewski, W.A. 1994: Nea Paphos 1993, PAM V, 101-110

Daszewski, W.A. 1995: Nea Paphos 1994, PAM VI, 67-74

Daszewski, W.A. 1996: Nea Paphos 1995, PAM VII, 91-99

Daszewski, W.A. 1997: Nea Paphos: Excavations 1996, PAM VIII, 113-121

Daszewski, W.A. 1998: Nea Paphos: Excavations 1997, PAM IX, 119-129

Daszewski, W.A. 1999: Nea Paphos: Excavations, 1998, PAM X, 163-173

Daszewski, W.A., Meyza, H., Machowski, W., Papuci-Władyka, E., Rądkowska, J.K., Wasilewska, O. 2010: Nea Paphos: Season 2007, PAM XIX, 503-514

Daszewski, W.A., Meyza, H., Papuci-Władyka, E. 2007: Nea Paphos: Season 2005, PAM XVII, 393-407

Daszewski, W.A., Meyza, H., Papuci-Władyka, E., Medeksza, S. 2004: Nea Paphos: Season 2003, PAM XV, 279-300

Daszewski, W.A., Meyza, H., Papuci-Władyka, E., Medeksza, S. 2008: Nea Paphos: Season 2006, PAM XVIII, 507-517

Ellis, S.P. 2000: Roman Housing, London

Gros, P. 2006: L’Architecture Romaine, du début du III siècle av. J.- C. à la fin du HautEmpire, vol. 2. Maisons, palais, villas et tombeaux, Paris

Hales, S. 2003: The Roman House and Social Identity, Cambridge

Jashemski, W.F., Gleason, K.L, Hartswick, K.J., Malek, A.-A. 2018: Gardens of the Roman Empire, Cambridge

Karageorghis, V. 1987: Chronique des fouilles et découvertes archéologiques à Chypre en 1986, BCH 111/2, 663-733

Karageorghis, V. 1988: Chronique des fouilles et découvertes archéologiques à Chypre en 1987, BCH 112/2, 793-855

Karageorghis, V. 1989: Chronique des fouilles et découvertes archéologiques à Chypre en 1988, BCH 113/2, 789-853

Majcherek, G. 1995: Alexandria 1994. Archaeological Excavations, PAM VI, 11-20

Majcherek, G. 1997: Alexandria. Kom el-Dikka Excavations 1995-1996, PAM VIII, 17-31

Majcherek, G. 2000: Kom el-Dikka Excavations 1998/99, PAM XI, 27-38

McKenzie, J. 1990: The Architecture of Petra, British Academy Monographs in Archaeology 1, Oxford

McKenzie, J.S. 2001: Keys from Egypt and the East: Observations on Nabataean Culture in the Light of Recent Discoveries, BASOR 324, 97-112

McKenzie, J. 2007: The Architecture of Alexandria and Egypt c. 300 BC to AD 700, New Haven

Medeksza, S. 1992: Willa Tezeusza w Nea Pafos. Rezydencja antyczna, Wrocław

Medeksza, S. 1998: Willa Tezeusza w Nea Pafos na Cyprze: powstanie i fazy rozwoju, [in:] Daszewski, W.A., Meyza, H. (Eds), Cypr w badaniach polskich, Materiały z sesji naukowej zorganizowanej przez Centrum Archeologii Śródziemnomorskiej UW im. prof. K. Michałowskiego, Warszawa 24-25 luty 1995,Warszawa, 25-50

Meyza, H. 2015: Nea Paphos. Seasons 2012 and 2013, PAM XXIV/1, 443-452 
Meyza, H., Daszewski, W.A., Brzozowska, A., Michalska, J., Rądkowska, J.K., Więch, M. 2012: Nea Paphos. Season 2009, PAM XXI, 407-422

Meyza, H., Daszewski, W.A., Zarzycka, M., Michalska-Bartoszek, J., Papuci-Władyka, E., Wasilewska, O., Więch, M. 2011: Nea Paphos. Season 2008, PAM XX, 283-294

Meyza, H., Romaniuk, M.M., Więch, M. with appendices by Mazanek-Somerlik, D., Więch, M. 2017: Nea Paphos: Seasons 2014 and 2016, PAM XXVI/1, 399-428

Meyza, H., Słowińska, M., Tybulewicz, R., Woźniak, M. 2014: Nea Paphos: Seasons 2010 and 2011, PAM XXIII/1, 391-401

Młynarczyk, J. 1990: Nea Paphos in the Hellenistic Period, Nea Paphos III, Varsovie Papageorghiou, A. 1990: Chronique des fouilles et découvertes archéologiques à Chypre en 1989, ВСH 114/2, 941-985

Papaioannou, M. 2010: The Evolution of the Atrium-House: A Cosmopolitan Dwelling in Roman Greece, [in:] Ladstätter, S., Scheibelreiter, V. (Eds.), Städtisches Wohnen im östlichen Mittelmeerraum 4. Jh. v. Chr.-1. Jh. n. Chr., Akten des internationalen Kolloquiums vom 24.-27. Oktober 2007 an der Österreichischen Akademie der Wissenschaften, Wien, 81-115

Pensabene, P. 1993: Elementi architettonici di Alessandria e di altri siti egiziani, Roma

Pensabene, P., Gasparini, E. 2020: Spreading of Alexandrian architectural types in the Eastern Mediterranean: the case of Cyprus, [in:] Meyza, H. (Ed.), Decoration of Hellenistic and Roman Buildings in Cyprus, Travaux de l'Institut des Cultures Méditerranéennes et Orientales de l'Académie Polonaise des Sciences 4, WarsawWiesbaden, 151-165

Rekowska, M. 2020: Decoration of houses in Cyprus and Cyrenaica: an architectural koiné? Towards research objectives and methodological approaches, [in:] Meyza, H. (Ed.), Decoration of Hellenistic and Roman Buildings in Cyprus, Travaux de l'Institut des Cultures Méditerranéennes et Orientales de l'Académie Polonaise des Sciences 4, Warsaw-Wiesbaden, 195-208

Romaniuk, M.M. 2017: A circular pool in the main courtyard of the "Hellenistic" House in Nea Paphos. Preliminary remarks, PAM XXVI/1, 429-440

Romaniuk, M.M. 2021: Terracotta Pipelines at Maloutena. Remarks on the Water System in the Residential District of Ancient Nea Paphos, Cyprus, EtudTrav XXXIV, 363-405

Rothe, U. 2018: The Roman Villa. Definitions and Variations, [in:] Marzano, A., Métraux, G.P.R. (Eds), The Roman Villa in the Mediterranean Basin: Late Republic to Late Antiquity, Cambridge, 42-58

Stucchi, S. 1975: Architettura Cirenaica, Roma

Vanderstar, P. 1997: The Classical Orders in Hellenistic and Roman Cyprus, unpublished PhD thesis, Oxford University, Oxford

Wallace-Hadrill, A. 1997: Rethinking the Roman atrium house, [in:] Laurence, R., WallaceHadrill, A. (Eds), Domestic Space in the Roman World: Pompeii and Beyond, JRA-Suppl. 22, Portsmouth, 219-240 
Weiss, Z. 2018: Houses of the Wealthy in Roman Galilee, [in:] Marzano, A., Métraux, G.P.R. (Eds), The Roman Villa in the Mediterranean Basin: Late Republic to Late Antiquity, Cambridge, 317-328

Więch, M. 2017: Searching for the Kitchen in the Early Roman Phase of the 'Hellenistic' House at Nea Paphos (Cyprus), EtudTrav XXX, 439-457

Wright, G.R.H. 1992: Architectural Details from the Asklepeion at Balagrae (Beida), LibStud 23, 45-72 


\section{ÉTUDES et TRAVAUX XXXIV / 2021}
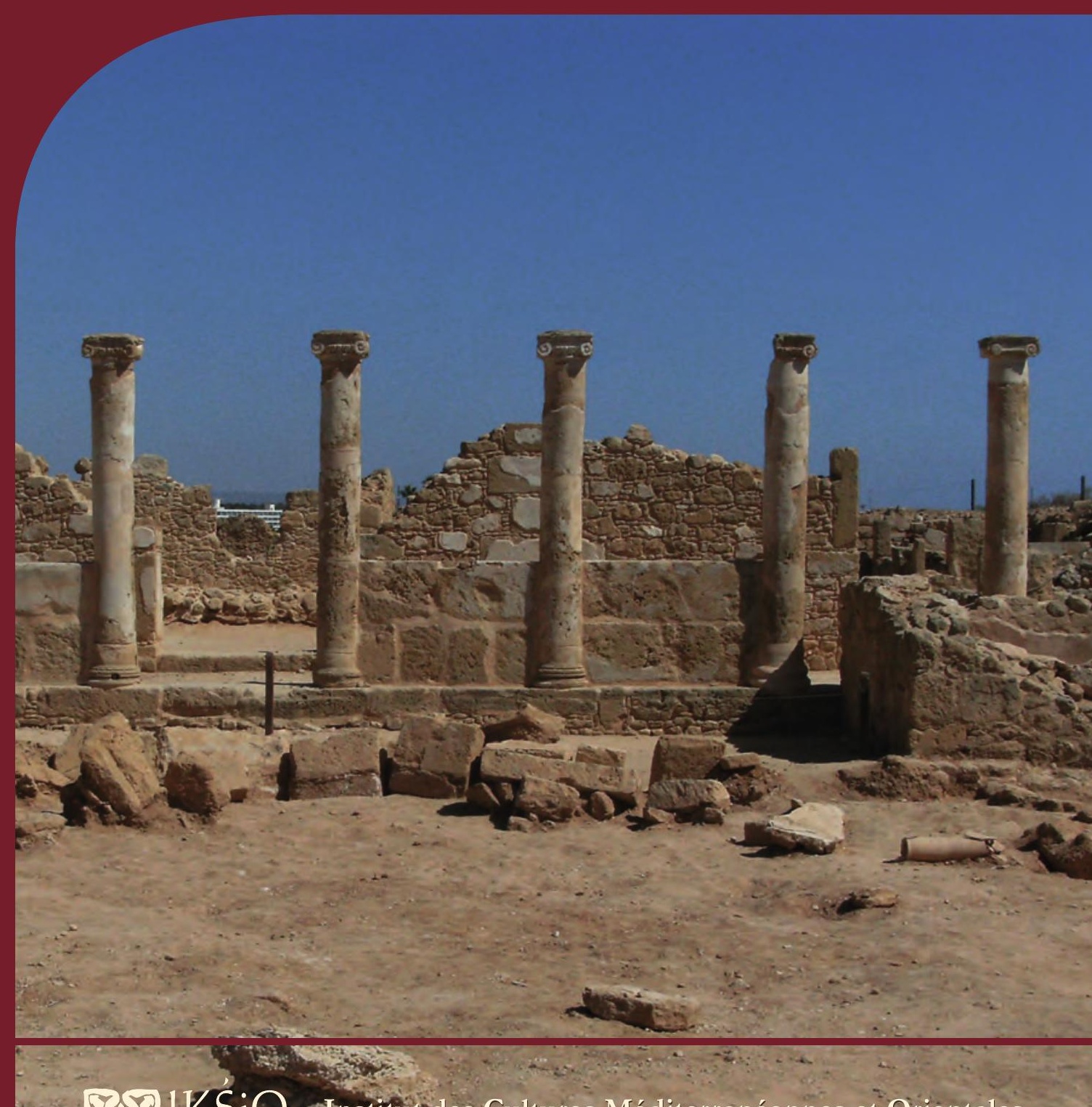

W $92 \mathrm{HKSiO}$ Institut des Cultures Méditerranéennes et Orientales

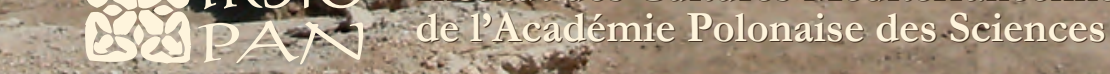

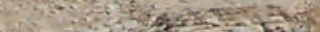

Q 
COMITÉ DE RÉDACTION SCIENTIFIQUE

Maciej Makowski - rédacteur en chef

Jadwiga Iwaszczuk - rédacteur

Katarzyna Kapiec - secrétaire de la rédaction

Henryk Meyza - rédacteur thématique du volume

CONSEIL SCIENTIFIQUE DU JOURNAL

M. Kobusiewicz (IAE PAN, Warszawa)

E. Laskowska-Kusztal (IMOC PAS, Warszawa)

D. Michaelides (University of Cyprus, Nicosia)

J.Ch. Moretti (IRAA-MOM, Université de Lyon 2/CNRS)

D. Raue (Ägyptisches Museum der Universität Leipzig)

P. Reynolds (ICREA, España)

D. Welsby (British Museum, London)

COMITÉ SCIENTIFIQUE DE LECTURE

la liste des membres du comité est accessible en ligne sur

http://www.etudesettravaux.iksiopan.pl

RÉDACTION TECHNIQUE

Marta Kaczanowicz

REVUE DES TEXTES EN ANGLAIS

Jo Harper 
ÉTUDES et TRAVAUX XXXIV 
INSTYTUT KULTUR ŚRÓDZIEMNOMORSKICH I ORIENTALNYCH POLSKIEJ AKADEMII NAUK

\title{
STUDIA i PRACE
}

\section{XXXIV}

\author{
GoIKSiO \\ QSO PAN \\ WARSZAWA \\ 2021
}


INSTITUT DES CULTURES MÉDITERRANÉENNES ET ORIENTALES DE L’ACADÉMIE POLONAISE DES SCIENCES

\section{ÉTUDES et TRAVAUX}

XXXIV

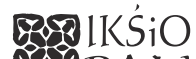

EOSPAN

VARSOVIE

2021 
Publication scientifique financée dans le cadre du programme du Ministre de la Science et de l’Éducation Supérieure

« Programme National de Développement de l’Humanistique » pour les années 2016-2021 (projet no 3bH 150099 83)

\title{
(1) NARODOWY PROGRAM ROZWOJU HUMANISTYKI
}

\author{
Copyright $(C)$ \\ Instytut Kultur Śródziemnomorskich i Orientalnych PAN \\ et les Auteurs \\ Warszawa 2021
}

ISSN 2084-6762

(jusqu'en 2011 : 0079-3566)

e-ISSN 2449-9579
Version première en papier, imprimée en Pologne - 150 copies
Version électronique accessible sur
http://www.etudesettravaux.iksiopan.pl

Édition: Polskie Towarzystwo Historyczne et Wydawnictwo Neriton, Warszawa

Conception générale de la couverture : J. Iwaszczuk

Photographie de couverture : Phot. A. Brzozowska-Jawornicka

(Le portique ionique est, péristyle de la Maison « hellénistique », Nea Paphos) 


\section{Table des matières}

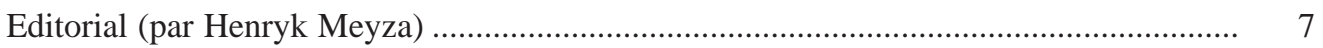

Marta BaJTLER

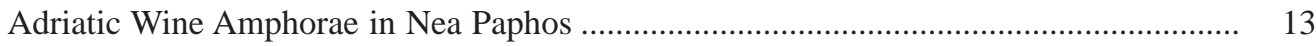

Claire Balandier, Jolanta MlynarczyK

The Temple and Its Surroundings on Fabrika Hill, Paphos: Preliminary Results

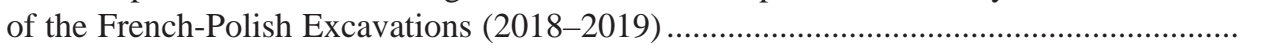

Grażyna BĄKowska-Czerner, Rafal CzERner

The Shell Motif in the Culture and Architecture of the Ancient Town of Marina el-Alamein in Egyp

AleKsandra BrzozowsKa-JaWornicKa

'Hellenistic' House in Nea Paphos, Cyprus - A First Summary of Its Architecture.

AleKsandra BrzozowsKa-JaWORnicKA, AnNa KuBICKA-SowińsKa

In Search of the Module in the Architectural Design of the 'Hellenistic'

House in Nea Paphos, Cyprus

RoKsana HaJduga

Kushite Stamp Impressions from Selib 2, Sudan

ERSIN HusSEIN

Mapping Metal Rich Roman Cyprus: The Case for Object-Centred Approaches

BARBARA LICHOCKA

Villa of Theseus at Nea Paphos (Cyprus). Fourth-Early Fifth Century Numismatic

Evidence for Architectural Transformations and Seismic Events

VASiliki Lysandrou, Demetrios Michaelides

Wall Paintings in Ancient Cyprus: The Hellenistic and Roman Tombs of Paphos

and Its Region

ADAM ŁAJTAR

A Weight of Seleucia in Pieria in Nea Paphos

Diana MroczeK

Ancient Portrait Busts of Marcus Aurelius in the National Museum in Poznań 
Brandon R. Olson, R. Scott Moore, Thomas Landvatter, Justin Stephens

Pyla-Vigla: A Case Study Assessing the Imperial Strategies of the Hellenistic

Diadochoi in Cyprus

Patrizio Pensabene, Eleonora Gasparini

Colonnaded Hall in Kourion: How the Oecus Corinthius Was Interpreted in the Roman

Houses of Cyprus

Monika Rekowska, Demetrios Michaelides, Skevi Christodoulou, JAKUB KANISZEWSKI

Adopting Roman Habits - The Baths in the House of Orpheus in Nea Paphos

as a 'Troublesome' Case Study?

MARCIN M. ROMANIUK

Terracotta Pipelines at Maloutena: Remarks on the Water System in the

Residential District of Ancient Nea Paphos, Cyprus

363

ABRÉVIATIONS

407 